\title{
Earliest history of coal mining and grindstone quarrying at Joggins, Nova Scotia, and its implications for the meaning of the place name "Joggins"
}

\author{
Howard J. Falcon-Lang \\ Department of Earth Sciences, University of Bristol, Bristol BS8 1RJ, UK \\ Present address: Department of Earth Sciences, Royal Holloway, University of London, \\ Egham, Surrey TW20 0EX, UK. <h.falcon-lang@es.rhul.ac.uk>
}

Date received: 03 October 2008 Date accepted: 06 December 2008

\begin{abstract}
The rich history of coal mining and grindstone quarrying at Joggins, Nova Scotia, prior to Lyell's visit in 1842 is less well known than its subsequent history. Franquelin first observed coal there in 1686, and within little more than a decade Acadian coal mines had sprung up at the Coal Cliffs. Following the British acquisition of Nova Scotia in 1713, the coal mines attracted Captain Belcher and other New England traders, who loaded their ships with coal for sale in Boston. In 1731, eager to impose duty on this unregulated trade, the Nova Scotia Council sponsored a British coal mine at Joggins operated by Major Cope. Unable to safely load ships at the Coal Cliffs, Cope constructed a wharf and coal depot at Gran'choggin (present-day Downing Cove), seven miles to the north of the mine. It was by association with this depot that the Coal Cliffs later became known as Joggins. Cope's coal mine survived less than eighteen months before the Mi'kmaq, aided and abetted by Acadians, destroyed the site in 1732. Following this episode, Acadians worked the Joggins coal mines until they fell under the control of British forces engaged in the Seven Years War in 1756. Subsequently, the Lords of Trade suppressed coal mining at Joggins, fearing it would harm British imports, and full-scale operations did not recommence until 1847. During this lull, the grindstone industry boomed. Beginning sometime before 1764, the principal stone quarries operated at Lower Cove, where the famous Blue-Grit was cut. Grindstone quarries were also worked on the Maringouin Peninsula and the two opposing sides of Chignecto Bay became known as the North and South Joggins.
\end{abstract}

\section{RÉSUMÉ}

On connaît moins bien le riche passé de l'extraction du charbon et de la pierre meulière à Joggins, Nouvelle-Écosse, avant la visite de Lyell en 1842, que son passé subséquent. Franquelin y avait observé du charbon pour la première fois en 1686 et en l'espace d'un peu plus d'une décennie, plusieurs mines de charbon acadiennes étaient apparues à Coal Cliffs. À la suite de l'acquisition de la Nouvelle-Écosse par les Britanniques en 1713, les mines de charbon ont attiré le capitaine Belcher et d'autres commerçants de la Nouvelle-Angleterre qui chargeaient leurs vaisseaux de charbon pour le vendre à Boston. En 1731, impatient d'imposer des droits sur ce commerce non réglementé, le Conseil de la Nouvelle-Écosse a parrainé l'exploitation à Joggins d'une mine de charbon britannique exploitée par le major Cope. Incapable de charger de façon sécuritaire les navires à Coal Cliffs, Cope construisit un quai et un dépôt de charbon à Gran'choggin (anse Downing actuelle), à sept milles au nord de la mine. L'association à ce dépôt a plus tard conféré à Coal Cliffs le nom de Joggins. La mine de charbon de Cope a subsisté moins de 18 mois jusqu’à ce que les Micmacs, aidés et soutenus par les Acadiens, détruisirent l'emplacement en 1732. Après cet épisode, les Acadiens ont exploité les mines de charbon de Joggins jusqu'à ce qu'elles tombent sous le contrôle des forces britanniques engagées dans la guerre de Sept Ans en 1756. Les lords du commerce ont subséquemment supprimé l'extraction du charbon à Joggins, par crainte qu'elle fasse tort aux importations britanniques, et l'exploitation à grande échelle n'a pas recommencé avant 1847. Pendant cette période d'accalmie, l'industrie de la pierre meulière a connu un essor notable. Les principales carrières de pierre ont commencé leurs activités dans les années ayant précédé 1764 à Lower Cove, où l'on extrayait le fameux grès dur bleu. Des carrières de pierre meule ont également été exploitées sur la péninsule Maringouin et les deux rives opposées de la baie Chignectou devinrent connues sous les noms de North et South Joggins.

[Traduit par la redaction] 


\section{INTRODUCTION}

The Joggins Section is a famous Carboniferous succession located on the southeastern shore of Chignecto Bay, Bay of Fundy, Nova Scotia. It begins at Mill Creek, at the axis of the Minudie Anticline, and extends as far as Shulie, some 20 $\mathrm{km}$ to the southwest (Fig. 1). This $\sim 4 \mathrm{~km}$ thick succession of Carboniferous rocks was first logged in its entirety by Logan (1845) and later described by Lyell (1871 p. 671) as "the finest example in the world of a natural [Carboniferous] exposure". Geologists have studied these extensive sea-cliffs for nearly two centuries, the most intensive work focusing on the coal-bearing strata located near the present-day community of Joggins (Falcon-Lang et al. 2006). The insights that have emerged from this work have addressed fundamental questions about the origin of coal, the history of life, and the nature of evolution (Cornell 1983; Falcon-Lang and Calder 2005; Calder 2006; Falcon-Lang 2006).

Most histories of the site begin on 28 July 1842 , the date that Charles Lyell (1797-1875) first explored the Joggins Section in the company of Abraham Gesner (1797-1864), the pioneering economic geologist (Miller and Buhay 2007). Without doubt, it was Lyell who brought the Joggins Section to a worldwide audience by writing about its coal-bearing strata and extraordinary fossil forests for both scientific and popular audiences (Lyell 1843, 1845). However, in focusing attention on Lyell's influential work, historians have tended to neglect the much earlier written records of the site (Calder 2006). The aim of this paper is to review this older literature and in particular to discuss the earliest history of coal mining and grindstone quarrying, which commenced in the late seventeenth century. This historical account, which relies on many previously unrecognized documents, additionally sheds light on the muchdebated etymology of the place name "Joggins".

\section{BEGINNINGS (1604-1692)}

Mineral exploration began in the Baie Française (later known as the Bay of Fundy) soon after French settlers arrived in 1604. Amongst the first colonists was Samuel de Champlain (1575-1635), Royal Cartographer to Henry IV of France, who recorded the occurrence of copper and iron at various sites (Grant 1907). After the settlement of Port Royal and the establishment of L'Acadie in 1605, the exploitation of mineral resources must have steadily increased by this growing French

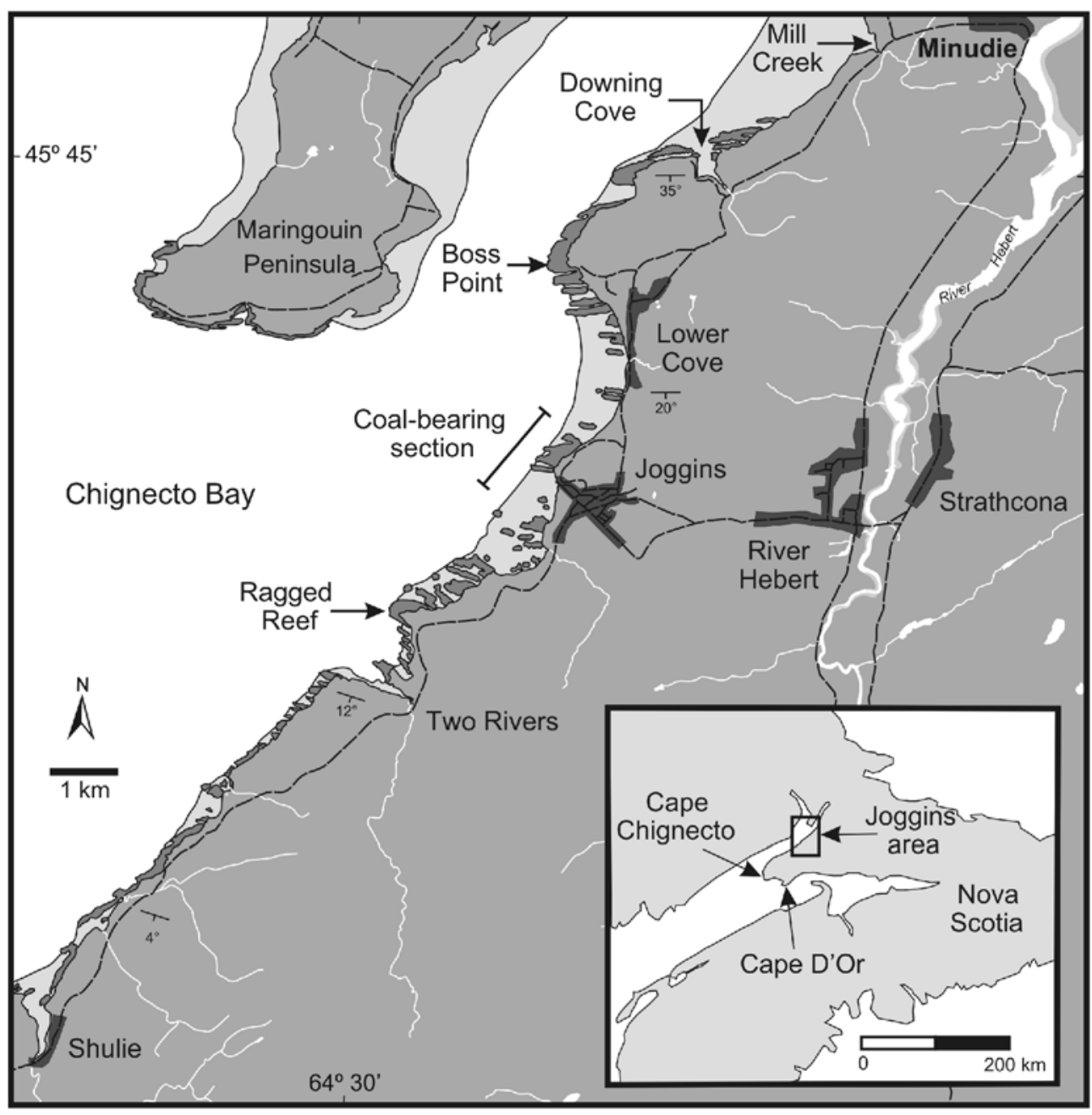

Fig. 1. Map of the Joggins Section from Mill Creek, at the axis of the Minudie Anticline, southwest to Shulie, showing the main geographic features mentioned in this paper. (Modified from fig. 2B, Rygel and Shipley 2005.) Inset: Map of Nova Scotia showing the location of the Joggins area. 
community. Nevertheless early references to coal are lacking, despite coal seams being readily accessible at several places on the Bay of Fundy and along the rivers that drain into it. This absence of records must be interpreted with caution, however, as localized coal extraction may not have resulted in any written documentation.

The first hint of any coal-mining activity on the Bay of Fundy is found among records of the Massachusetts Bay Colony in New England. These document a shipment of coal, in 1639, from the Bay of Fundy to the newly founded settlement of Boston(Shurtleff 1853). We do not know exactly from where this coal had been extracted or how long mining operations had been in progress. However, four years later, John Winthrop (1587/8-1649), Governor of the Massachusetts Bay Colony, made a second reference to coal. In his journal entry for 6 September 1643, he described how a vessel "went up [Saint] John's river some 20 leagues and loaded with coal" (Dunn et al. 1996, p. 474). This description pinpoints the location of coal extraction to the Grand Lake region of presentday New Brunswick, where coal-bearing strata of Bolsovian age occur. Was coal also being extracted on the Joggins Section in Chignecto Bay at this time? We do not have any evidence but neither can we rule out the possibility entirely. Overall, it seems unlikely as Chignecto Bay was yet to be settled by the French.

The famous diarist, Samuel Pepys (1633-1703), based in London, England, made a third reference to coal on the Bay of Fundy in 1667. In his journal entry for 8 September, Pepys described how the region "hath a river 300 miles up the country, with copper more than Swedeland, and Newcastle coals" and noted that this was "the only place in America that hath coals that we know of" (Braybrooke 1825, p. 1864). Most commentators have interpreted this as another reference to the coal operations at Grand Lake (Martin 2003). However, Pepys implied that coal and copper occurred in close association, and at that time, the centre of copper extraction was around Chignecto Bay. It is just possible that Pepys' reference to Newcastle coals was an allusion to the coal-bearing strata of the Joggins Section (which are more easily accessible than those at Grand Lake). Whatever the location of Pepys' "Newcastle coals", the fact that news of their existence had reached London indicates just how well known the coals of the Bay of Fundy had become.

A much more substantial, but still uncertain, reference to the coal-bearing strata of the Joggins Section occurs on late seventeenth century maps issued by Jacques de Meulles (died 1703). De Meulles, the Intendant of New France, visited the area surrounding Chignecto Bay (then known as Chignitou or Beaubassin) in 1686. Accompanying him was Jean-Baptiste Louis Franquelin (1653-1712), Hydrographer to King Louis XIV, who was probably responsible for preparing the maps (Charbonneau 1972). Several of Franquelin's maps have survived. One detailed map (Franquelin 1686) precisely depicts the marshes, rivers, and coastline of Chignecto Bay, but makes no reference to coal (Fig. 2). However, another map (Franquelin 1702) has the label Ance au Charbon ("Coal Cove") adjacent to the coastal outcrop belt of the coal-bearing strata at present day Joggins (Fig. 3). Although this latter map is dated 1702, Franquelin's only visit to Chignecto Bay was in 1686, so it is likely it depicts the geography as it was at the earlier date (Charbonneau 1972). This is supported by the fact that the map shows the settlement at Beaubassin on Chignecto Bay, founded in 1671, but not the settlement in the Minas Basin, which was founded shortly after Franquelin's visit (Paul Bogaard, pers. comm. 2008). Although Franquelin's annotation, Ance au Charbon does not strictly indicate the existence of coal mines, it clearly shows that settlers were well aware of the existence of the coal deposits at Joggins, and were likely utilizing them in a limited way.

Yet another reference to coal at a site that is almost certainly the coastal cliffs at Joggins was made in 1692 by the soldier, explorer and administrator Antoine Laumet de la Mothe, sieur de Cadillac (1658-1730). In his Mémoire de l'Acadie, Nouvelle Angleterre, Nouvelle Hollande, et Virginie, he briefly observed that "there is some coal" in Beaubassin (Ganong 1930, p. 89). Coal seams crop out with sufficient prominence to be seen from a ship at only two locations on Chignecto Bay. The first location is at present-day Spicer's Cove, near Cape Chignecto (Fig. 1), where a few coals of late Duckmantian age crop out, and the second is at Joggins, where thick economic coals occur in the middle to upper Langsettian Joggins Formation (FalconLang et al. 2006). Thus, Joggins with its much more extensive coals is by far the most likely object of Laumet's observations.

\section{EARLY ACADIAN COAL MINES (1692-1731)}

In 1710, the French settlement at Port Royal was captured by British forces and renamed Annapolis Royal. Three years later under the terms of the Treaty of Utrecht, L'Acadie was annexed by Britain and became known as Nova Scotia. The earliest specific reference to the existence of coal mines at Joggins occur in the Letter-Books of the British Governors of Nova Scotia (reprinted in MacMechan 1900) and date from the very start of British occupation. An entry for 1713, written by Governor Francis Nicholson (1655-1728) from Annapolis Royal, makes the following cryptic observation: "no harbor within two leagues of the coal mine, and no vessel can be loaded without grounding; no boat can land for the sea" (MacMechan 1900, p. 1). Although the location of this coal mine is not divulged, and the context of the note provides no further clues, a later report written in 1715 by Governor Thomas Caulfield (1685-1717) explicitly positions the site at "Checanectou" (Chignecto) at the head of the Bay of Fundy, and elaborates: "very good coal mines there, which have formerly been used by this garrison" (MacMechan 1900, p. 25). The garrison mentioned was the British garrison at Annapolis Royal, and implies that British soldiers had sporadically worked the coal mines at Joggins since the beginning of their occupation in 1710 .

The next reference to the Joggins coal mines is a complaint, made in 1720, concerning the unregulated trade between New England and Nova Scotia, which was draining resources south of the border. From Annapolis Royal, Governor Richard 


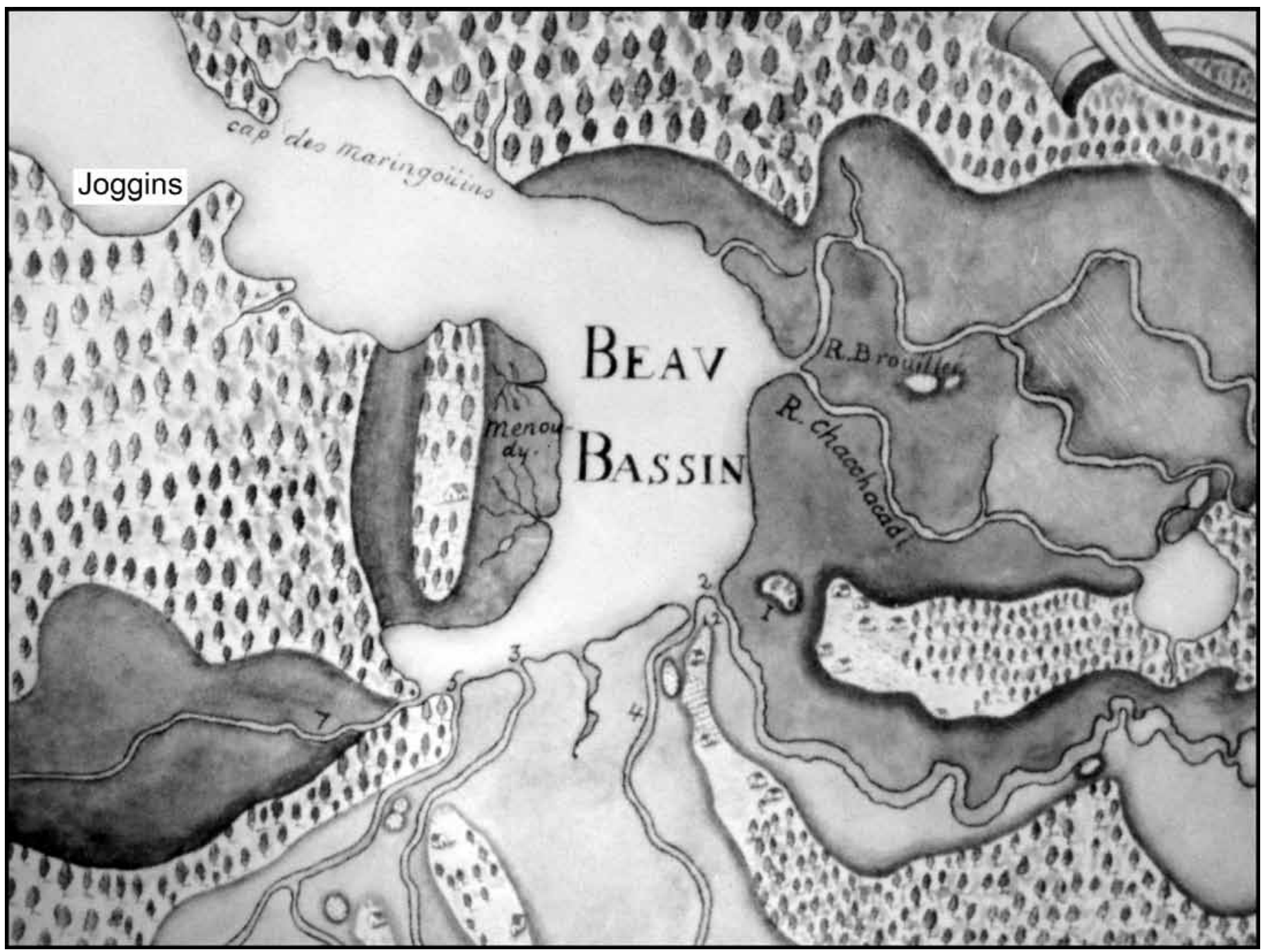

Fig. 2. Portion of a detailed map of Chignecto Bay, drawn up Franquelin (1686), which accurately shows the coastline, marshes and forests, but fails to make any reference to coal or coal mines. The location of the coal-bearing cliffs at presentday Joggins is shown. Courtesy of the Ralph Pickard Bell Library, Mount Allison University.

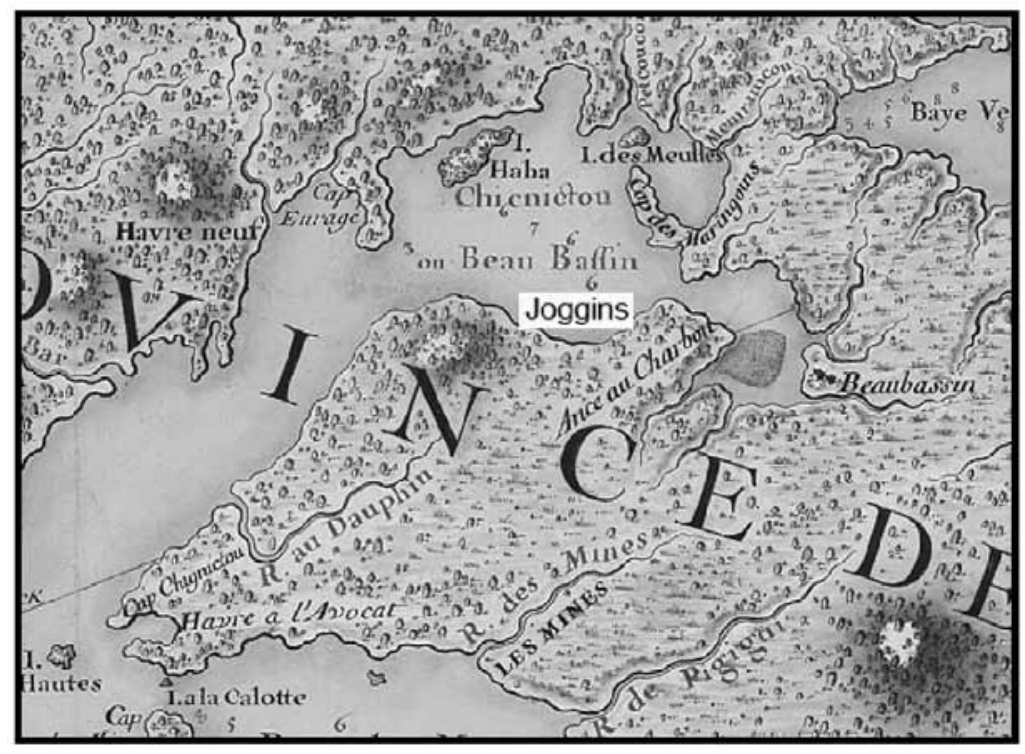

Fig. 3. Portion of a map of Chignecto Bay produced by Franquelin (1702) clearly showing "Ance au charbon" (Coal Cove). The location of the coal-bearing cliffs at present-day Joggins is shown. Courtesy of Paul Bogaard, Mount Allison University. 
Phillips (1661-1750), in reviewing this issue, remarked that "there is likewise in the upper part of the Bay [of Fundy], a very good Coal mine, which the people of Boston fetch at their pleasure not only without paying any acknowledgement to the Lord of the Manor (His Majesty) but without the good manners to ask his leave" (in Shortt et al. 1933, p. 126). This fits well with independent reports of coal shortages in Boston at that time. In fact such was the demand for coal in Boston that in 1717 a committee was set up "to Consider \& make Enquiry abt Encouraging the bringing of Sea Coal into this Town" (Roberts 1895, p. 396).

One of the main protagonists in the illicit trade of coal between Joggins and New England was Captain Andrew Belcher (1648-1717), a wealthy merchant who operated a fleet of trading ships out of Boston (Hale 1731). As Belcher died in 1717, this indicates that imports of Joggins coal began at an early date (probably since 1710); his son, Jonathan Belcher (16821757), carried on the business after his death (Bridenbaugh 2007). However, evidently Belcher's shipping fleet was only the tip of the iceberg. A decade later, in August 1727, two sloops, the Hopewell and Endeavour, were given formal "permission to Go up the Bay [of Fundy] to take in a load of coal to carry to Boston", but many more ships must have plied this route unregulated and unobserved (in Shortt et al. 1933, p. 167). Throughout most of this period, Acadians in Beaubassin (Chignitou) worked the Joggins coal mines, freely trading with their British neighbours in New England.

Most of what we reliably know of these early Acadian coal mines is inferred from a travelogue, written in 1731, by Robert Hale (1702-1767). Hale was a doctor and teacher from Beverly, Massachusetts (Wagner 1974), who became involved in a venture to transport coal from Joggins to New England. Departing Boston on 6 June 1731 on the schooner, Cupid, which he part owned, Hale arrived at the Joggins coal mines nineteen days later (Hale 1731). There can be no doubt about the location of these coal mines, as Hale describes his passage up the Bay of Fundy, navigating to the south of Cape Anroshia (Cape Enrage), before arriving at his destination on 25 June 1731. Early on that day, he observed, "wee past by the Coal Banks \& a little farther come to the place where Coal is taken in which is about 5 Lgs below Meskquesh ye cheif place of Checnecto" (Hale 1731, p. 229). Meskquesh (also known as Beaubassin) was the Acadian community established on the mouth of Missaguash River, which drains the Tantramar Marshes.

Hale (1731) makes some brief allusions to the history of Acadian coal mining operations at Joggins, noting that "Coal has been dug here this 30 years, but they alwayes us'd to land it up below high water mark, but now they dig it out of the Cliff near an 100 feet above" (Hale 1731, p. 229). If the source of Hale's intelligence is reliable (presumably he discussed the matter with Acadian miners), this indicates that mining may have begun around 1701, or thereabouts. It also implies that coal was initially extracted from outcrops on the wave-cut platform, as one can do today. As this source of coal eventually became scarce, seams were then followed back into the cliff and "coal-pits" dug. Hale's reference to 100-foot high cliffs is crucial for precisely positioning the coal-mine site. Of the workable coal seams at Joggins, only the Fundy and Forty Brine seams are associated with cliffs of this magnitude, and of these the Fundy Seam is the thicker, better quality coal.

Timbers supporting a system of shallow adits have been eroding out of the level of the Fundy Seam for many years (Goudge 1945) and may represent remains of these early Acadian coal mines (Fig. 4). However, more likely they date from younger excavations at the "New Mine", an operation begun in 1865 that involved an adit driven into the Fundy Seam at shore level, just above the high tide mark (Dawson 1868). Dendrochronological studies are in progress to determine their exact age. Nevertheless, historical records also indicate the existence of earlier timber workings at this site. When Jackson and Alger (1829, p. 149) reconnoitred the Joggins shoreline in 1829 they encountered a "shaft filled in with earth and rubbish" at the level of the Fundy Seam. Furthermore Copeland (1958) mentioned seeing an historic map showing "old French workings" (p. 7) on the Fundy Seam, but gave no details. In view of these observations, it is likely that Acadian workings were visible in the Fundy Seam until the early nineteenth century, but have subsequently been either destroyed by cliff erosion or reworked by later mining activity.

The minutes of the Nova Scotia Council for 1734 name René and Bernard LeBlanc as the "discoverers" of the Joggins coal measures (Shortt et al. 1933, p. 401). According to the Census of 1701, René LeBlanc (1684-1758) was a seventeen-year-old unmarried man living near Grand Pré in the Minas Basin at the time that coal started to be worked (Clark 1968), so this attribution seems plausible. LeBlanc was later a well known Acadian notary and collaborated with British forces based in Annapolis Royal (Clark 1968). The early date of LeBlanc's discovery means that Joggins was one of first sites to be mined for coal anywhere in North America. As already noted, earlier coal mines operated only at Grand Lake, New Brunswick, from 1639 (W.A. Bell 1965), in Cape Breton, from 1672 (Aston 1999), and possibly near Murphysboro, Illinois, from 1679.

Eighteenth century maps confirm the early written history of the Joggins coal mines. A map drawn by Captain John Wells, and enclosed in a dispatch from Governor Caulfield in 1715, marks "ye coals" at the site of present-day Joggins (Wells 1714), while a similar annotation occurs on a map produced by Captain Cyprian Southack, dating from 1716 (Paul Bogaard, pers. comm. 2008). A third significant map is that by Nathaniel Blackmore (died 1716), who surveyed the coastline of L'Acadie between November 1711 and September 1712 on board the brigantine Betty (Robinson 1976). His chart, which was eventually published in the Atlas Minor of Moll (1732), shows "Coale Cliffs" on the southeast side of Chignecto Bay (Fig. 5). However, this crucial annotation is missing from his original hand drawn map (Blackmore 1714-1715) as well as on the later map of Moll (1717), which is based on Blackmore's survey. Other maps in the Atlas Minor, Moll $(1720,1730)$, do show the "Coale Cliffs", so perhaps this feature was later added to Blackmore's chart based on observations after 1717. Nevertheless it demonstrates that, by 1720 , the Joggins coal mines were a prominent feature 


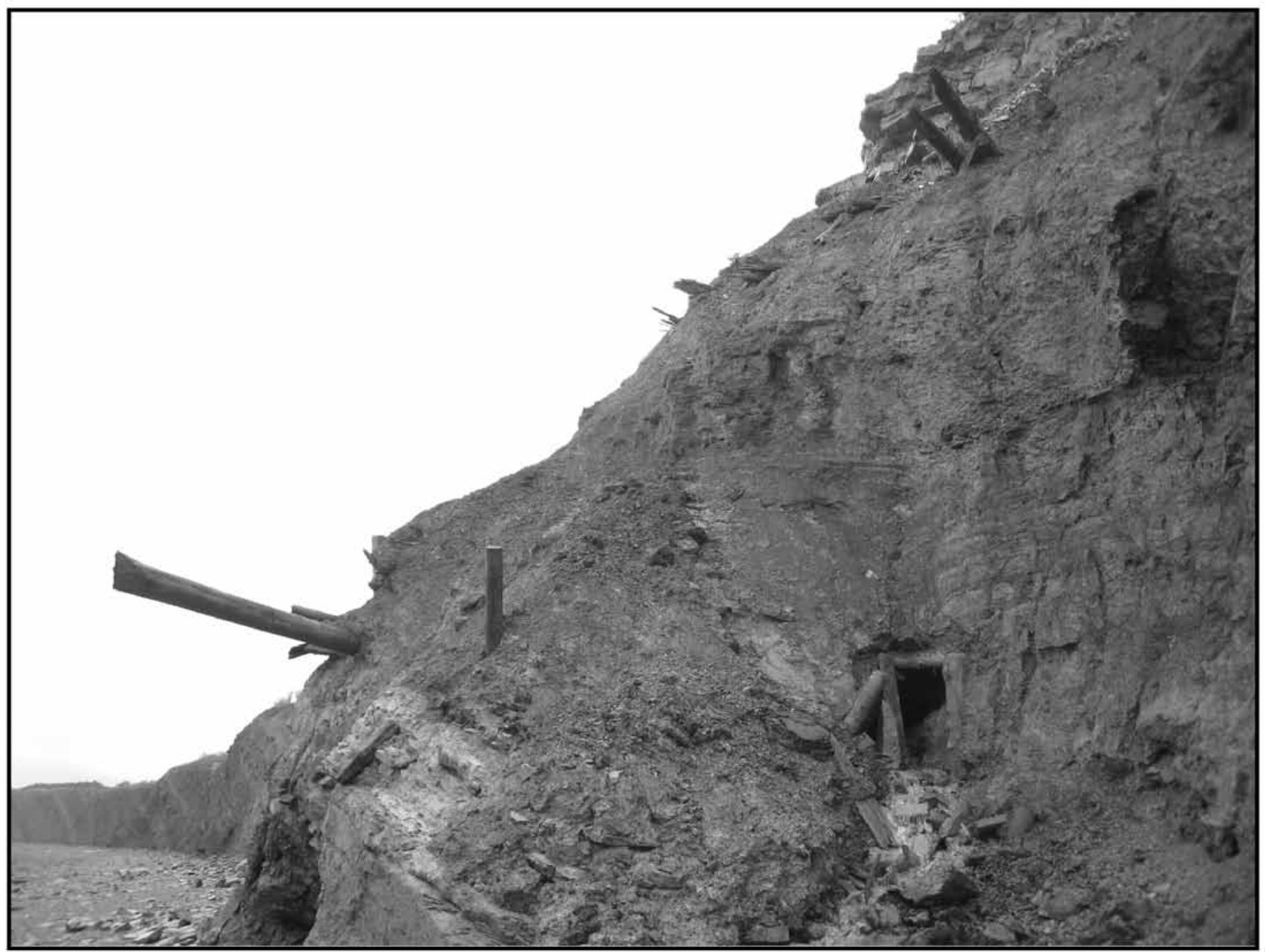

Fig. 4. The Fundy Seam at Joggins, showing timber pit props supporting a system of adits. These workings probably date from a later episode of mining in 1865, but according to Copeland $(1958$, p. 7$)$ "old French workings" were visible at this site in the early nineteenth century (Jackson and Alger 1829).

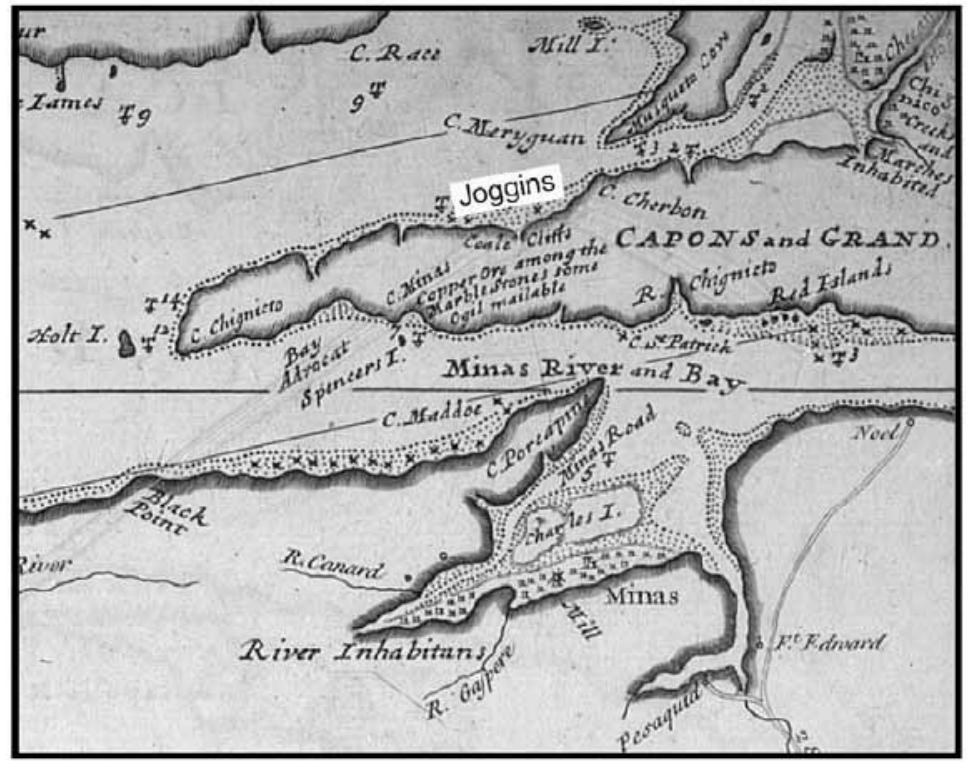

Fig. 5. Portion of Nathaniel Blackmore's map of the Bay of Fundy surveyed in 1711-1712, drawn up 1714-1715, and published in the Atlas Minor of Moll (1732). The crucial annotations of "Coale Cliffs" and "C. Cherbon" (Coal Cape) do not appear on the manuscript copy of the map (Blackmore 1714-1715), so they may have been added later. Nevertheless they do appear on the map by Moll (1720). The location of the coal-bearing cliffs at present-day Joggins is shown. This version of the map shows some later annotations around the Minas Basin. Courtesy of McGill University. 


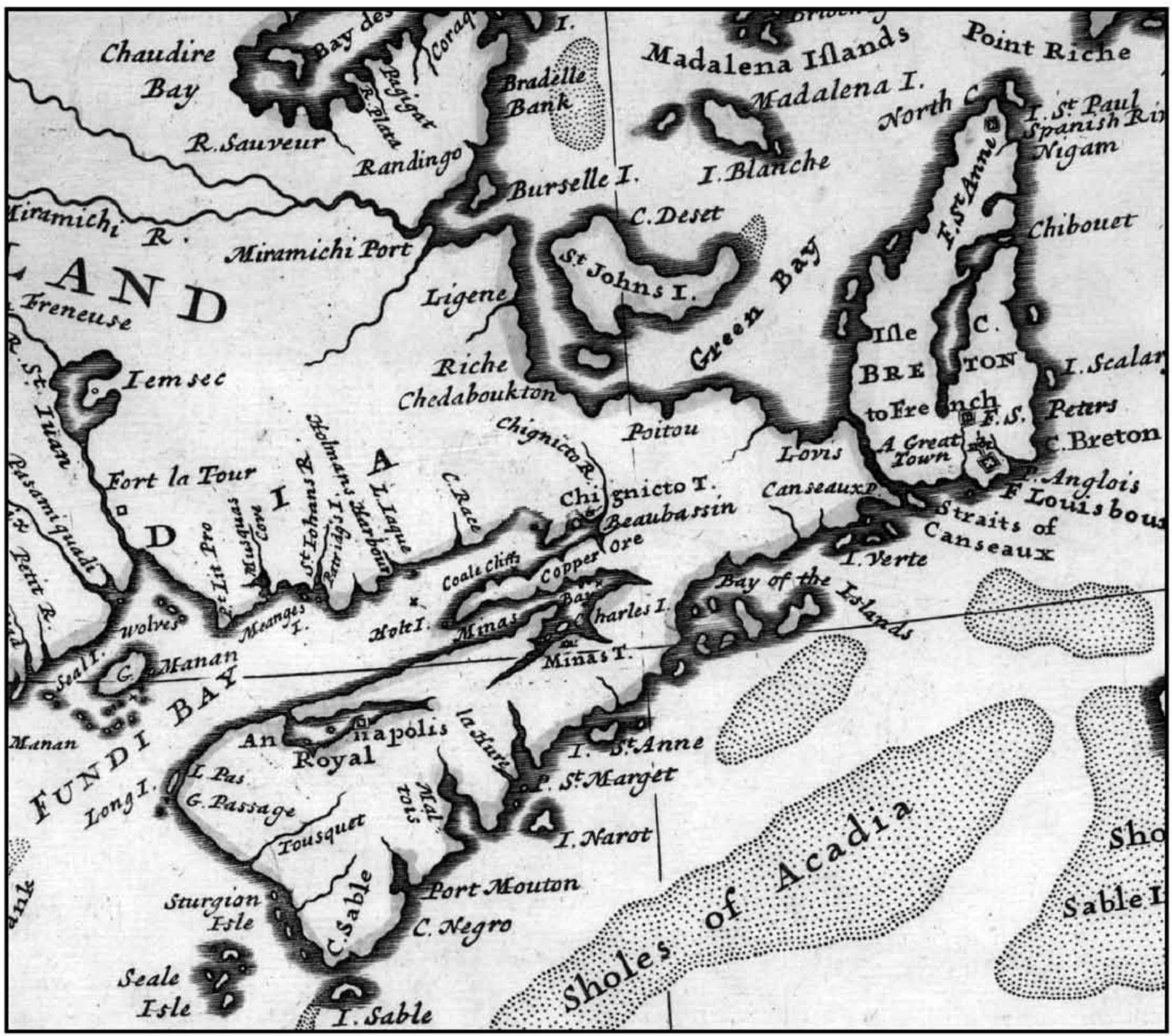

Fig. 6. Portion of Hermann Moll's map of North America (1730) showing the "Coale Cliffs" of Joggins as one of the most prominent features of the Bay of Fundy, Nova Scotia. Courtesy of the Centre for Newfoundland Studies, Memorial University Libraries.

of the Bay of Fundy, and perhaps one of the most important sites on the coast of Nova Scotia (Fig. 6).

\section{MAJOR HENRY COPE'S COAL MINE}

(1731-1735)

It seems that Robert Hale arrived at a very significant moment in the history of coal mining at Joggins. Until 1731, the year of his arrival, coal had been principally mined for the use of Acadians in Beaubassin, who numbered only about 200 in 1701 and about 350 in 1713 (Trueman 1902; Bird 1955), as well as for the occasional supply of entrepreneurs trading out of Boston and British soldiers (Shortt et al. 1933). However, in 1730, Governor Richard Phillips decided to assert greater control over the Acadian people and their commerce, demanding that they swear an oath of allegiance to King George II. On April 28, 1730, Mr Blin, a merchant, was dispatched "to make known [this proclamation] to the inhabitants at the mines of Chignitou" (Anon. 1888, p. 191). Although most Acadian submitted to these terms, "seventeen of those of Chignitou" refused to conform and "four deputies" were appointed to police the region (Murdoch 1865, p. 459-460).

Against this backdrop, later in 1730, Governor Phillips gave tacit approval to a proposal to establish a state-sponsored British coal mine at Joggins. He noted that "there are at this 
time some persons about makeing a tryal whether they can digg ye coal and Load Vessels [at Chickenectua] and if found Practicable intend to apply to the Government for leave to export it to New England" (Innes 1977, p. 28). Those "persons" were Major Henry Cope (1688-1742) and his Boston business partners, Captain Alexander Forsyth, Mr. John Liddel, and Mr. John Carnes (Thomas 1974). Cope, a military officer, entrepreneur and member of the Nova Scotia Council at Annapolis Royal, invested a lot of his own money in this project (Plank 1996) and in a remarkably short time, his mining operations commenced at Joggins in April 1731. Six British soldiers were brought from Annapolis Royal to protect Cope's coal mine and a team of 10-12 Acadians were employed to do the hard work of mining. A sergeant was employed as tax collector. Evidently there were rich pickings to be had for Cope and his partners because, as Hale (1731, p. 230) reported, "one man [could] dig many Chaldron of this Coal in a day" - a chaldron being slightly more than one tonne. This new enterprise was evidently the stimulus for Robert Hale's business trip in June 1731 , and he remarked that his ship was only the third to load up with coal (Hale 1731).

One logistical problem faced by Cope was how to safely load coal onto ships as the coast adjacent to the coal mines suffered from high tides, storms, and rocky shallows. This issue had been highlighted in 1713 and again in a report of 17201721 (Murdoch 1865, p. 396), which observed that "shelter is wanting for the vessels, which have to anchor in the open bay". Rather than load ships at the "Coal Cliffs", Cope decided to stockpile coal at the sheltered mouth of a creek, seven miles to the north. As discussed below, this creek was "call'd Gran'choggin" from which the name Joggins later arose (Fig. 7). Coal was carried to the creek in two small boats called lighters. As Hale (1731, p. 230) noted "this Creek is the nearest place to transport the Coal to where a Vessel may ride or lay Safely all Weathers, for tis dry half a Mile below the Wharf at low water".

Hale (1731, p. 230) further commented that Captain Belcher had used this site for the same purposes several years earlier (probably from 1710-1717). "Capt. Belcher of Boston, formerly caus'd coal to be dug here \& brought to the very place where the Wharffe now stands, \& a large quantity of it lyes there now, which was sett on fire (being mixed with much dirt) about 3 weeks agoe, \& the Fire is not out yet”. The earliest indication that Gran'choggin was used as a coal depot is the chart by Blackmore (1714-1715), which labels Boss Point and Downing Cove as "C. Cherbon" (Coal Cape), suggesting an association with Acadian coal mining activity from before 1711, the date of Blackmore's survey.

At the mouth of Gran'choggin, Cope constructed a makeshift wharf and cut a channel into marsh peat deep enough that a "vessel can go in a little before highwater" (Hale 1731, p. 230). However, even with this wharf in place, docking and loading Hale's schooner proved extremely challenging. After twice running aground on a falling tide, Hale (1731, p. 230) reported on 26 June how he eventually got the "Vessel in to the Wharf". He then "took our Cask out of the Hold, \& Capt. Foresyth's Hands went to Loading \& put in as much Coal as

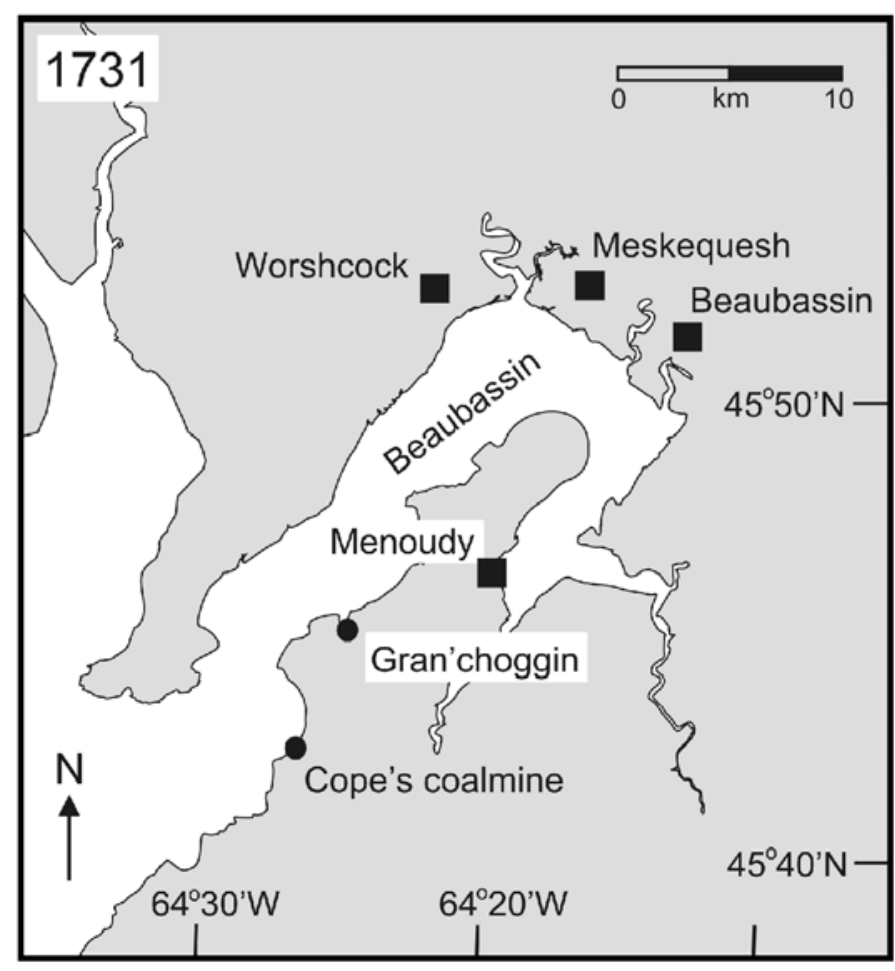

Fig. 7. Map of Beaubassin around 1731, the year that Major Henry Cope opened his coal mine and wharf at Gran'choggin (black circles). Acadian settlements are depicted by black squares (Clark 1968) and labeled using the spelling of Hale (1731), who visited Worshcock and Meskequesh.

wee tho't our Schooner wou'd float with". Afterwards, in thick fog, Hale took a three-day tour of Acadian settlements on the Chignecto Isthmus, including "Worshcock" (Westcock) and "Meskequesh" (Beaubassin), observing on the way the "wigwams" of Mi'kmaq communities. On 30 June 1731, Hale departed Beaubassin, carrying off some sixty tons of coal for the market at Charlestown Ferry in Boston, Massachusetts.

Cope's coal mining business at Joggins clearly made a very promising start, supplying a thriving market in Boston, and receiving financial backing from the Nova Scotia Council in Annapolis Royal on 24 June 1731 (Murdoch 1865, p. 473). Although an initial request for a land grant was rejected on 18 November 1731 due to wrangling over terms and conditions (MacMechan 1900, p. 80-81), on 21 June 1732, Cope and his partners were eventually granted 4000 acres of land on the peninsula to develop the "Coaliary near to Chickenectua" (MacMechan 1908, p. 227). In making the land grant, new geographic terms were devised to describe the area. The "Coal Clifts" were renamed "Adventurer's Clifts" and the coal depot at "Grandnajagan" was renamed "New Castle Cove" (MacMechan 1908, p. 232), presumably after Newcastle in Britain, which was the main source of coal imports to North America. The agreed terms of the land grant were that Cope and Company would pay duty of one shilling and sixpence per chaldron of coal extracted, set aside coal reserves for use 
at the garrison at Annapolis Royal, build four houses on the site within three years (forming the core of a proposed township to be called Williamstown), and cultivate a tenth of the land (Murdoch 1865, p. 485). Cope imagined that the coal reserves present on his property were substantial, supposing that they stretched in a continuous belt as far as Spanish River in Cape Breton (at the site of present-day Sydney Mines), where Acadians had been mining coal since 1672 (Murdoch 1865). However, offering a word of caution to this upbeat appraisal, he additionally noted that "the Coal in its own Nature [is] So very Changeable" (MacMechan 1900, p. 80-81).

In the end, Cope's coal-mining venture proved to be very short-lived, and by November 1732, had been entirely abandoned (Plank 1996), resulting a total loss of some $\mathfrak{f} 3000$ (the equivalent of about $£ 4$ million in 2008). Although details are sketchy, it seems that Cope infuriated Acadians by demanding rent to dig for coal on his land. In response, the Acadians incited local Mi'kmaq to attack and rob Cope's property (MacMechan 1900). Stanwell Hall, the first house that Cope had built (Hale 1731), was destroyed by three Mi'kmaq men, as was the mine, magazine and storehouses; all stock and goods were robbed (P.H. Smith 1884, p. 121). Operations were finally wound up when Cope defaulted on wage payments to the men in his employment. In January 1733, he tried to resurrect the colliery, in partnership with James Brydges, First Duke of Chandos (1674-1744) and Governor Phillips. The plan hinged on the construction of blockhouses at the "Coal Cliffs" to station a protective military force. However, this proved unsuccessful, and in 1739 Brydges referred to the whole episode as a fiasco (Baker and Baker 1949, p. 351). Whether the blockhouses were ever built is unknown, although over a century later, Gesner (1849, p. 35) described an old fort built over the coal-bearing strata, which had partly toppled over the cliff.

\section{COAL MINES BEFORE AND AFTER THE GRAND DÉRANGEMENT (1735-1760)}

The history of Joggins and its coal mines is relatively poorly known in the decade immediately after Cope's failed venture. In 1735, two of His Majesty's surveyors, George Mitchell and Edward Amherst, were sent to map the Chignecto Peninsula for the purpose of transferring Cope's land grant to another recipient (Mitchell and Amhurst 1735). Their detailed map highlighted the "Coal Clifts" as well as the coal-depot at "Grand Nyjagen”. Lawrence Armstrong (1664-1739), acting on behalf of Governor Phillips, was keen that this area be colonized to allow Britain to assert greater control over this part of Nova Scotia. Colonel John Hart (died 1740), the former governor of the Leeward Islands and a member of the Nova Scotia Council, wanted to take complete control of this land himself; but his proposal was rejected in September 1735 (Murdoch 1865, p. 507).

On 30 August 1736, following a year of wrangling, a fifty-thousand-acre plot of land comprising the Chignecto
Peninsula south of "Petite Nyagan" (present-day Mill Creek) was distributed between thirty-five grantees, including Hart, Cope and others on the Nova Scotia Council (Murdoch 1865, p. 519). The terms stipulated that the grant would be escheated should a settlement of fifty houses not be established on the site within three years. The proposed settlement was to be named Norwich (in the county of Norfolk, Nova Scotia), but it was never realized and the grant was dissolved on 21 April 1760 (Murdoch 1865, p. 519). In the year of the land grant (1736), Thomas Durrel (1685-1741), a British sea captain passed through Chignecto Bay and drew one of the most detailed charts of the Joggins region (Fergusson 1955), clearly depicting the "Sea Coal Cliffs" and their relation to the coal depot a few miles to the north at "Grand Jogin" (Fig. 8).

In the decade that followed these events, British influence in Chignecto Bay waned and Acadian settlements dramatically expanded. The Acadian population around Chignecto Bay reached 1816 people in 1737 and had exceeded 2800 people by 1750 , a period that constituted something of a golden age for Acadian culture (Trueman 1902; Bird 1955). Throughout this interval, Acadians appear to have reclaimed the coal mines and may have extended them inland, establishing a string of coalpits along the outcrop belt from present-day Joggins to River Hebert. The latter became known as "Rivère des Mines des Hébert" by 1750 and was labelled "Des Mines" in Evan Lewis's map of 1755 (reproduced in Surette 2005). The exact significant of this reference to mines is somewhat uncertain (Paul Bogaard, pers. comm. 2008), however, as a map dated 1753 also shows copper mines at River Hebert (Anon. 1753). Inland coal mining operations, if they occurred at all, must have been on a very small scale because, even as late as the 1820 s, "thin veins of coal" could still be observed to crop out along the banks of River Hebert (Jackson and Alger 1829; Gesner 1836).

In 1748 Britain prepared to assert greater control over Nova Scotia, and this signalled the beginning of the end of the Acadian coal mining industry at Joggins. An initial British survey of the mineral wealth of the province appears to have overlooked the coal-bearing strata at Joggins (Little 1748). Nor did they appear on a map of the upper part of the Bay of Fundy prepared by Charles Morris (1711-1781), Chief Surveyor to the Governor, who had been dispatched to ascertain opportunities for British colonization (Morris 1748). However, the following year, as Britain established its new fortress at Halifax, records of the coal workings resurfaced in a description of Nova Scotia published in the influential London Magazine (Anon. 1749). This article noted that there was "plenty of mineral coal for firing" forges on the Bay of Fundy, which "must be esteemed a great natural advantage" (Anon. 1749, p. 182). Referring to Copes' failed venture, seventeen years earlier, the article continued: "some years ago a company was set on foot in New England, in order to work the mines: But tho' that project was soon dropped with loss, a better use will, doubtless, be made of this treasure, when Nova Scotia itself comes to be inhabited" (Anon. 1749, p. 182).

A crucial moment in the development of the Joggins coal measures arrived in 1750 when Governor Edward Cornwallis 


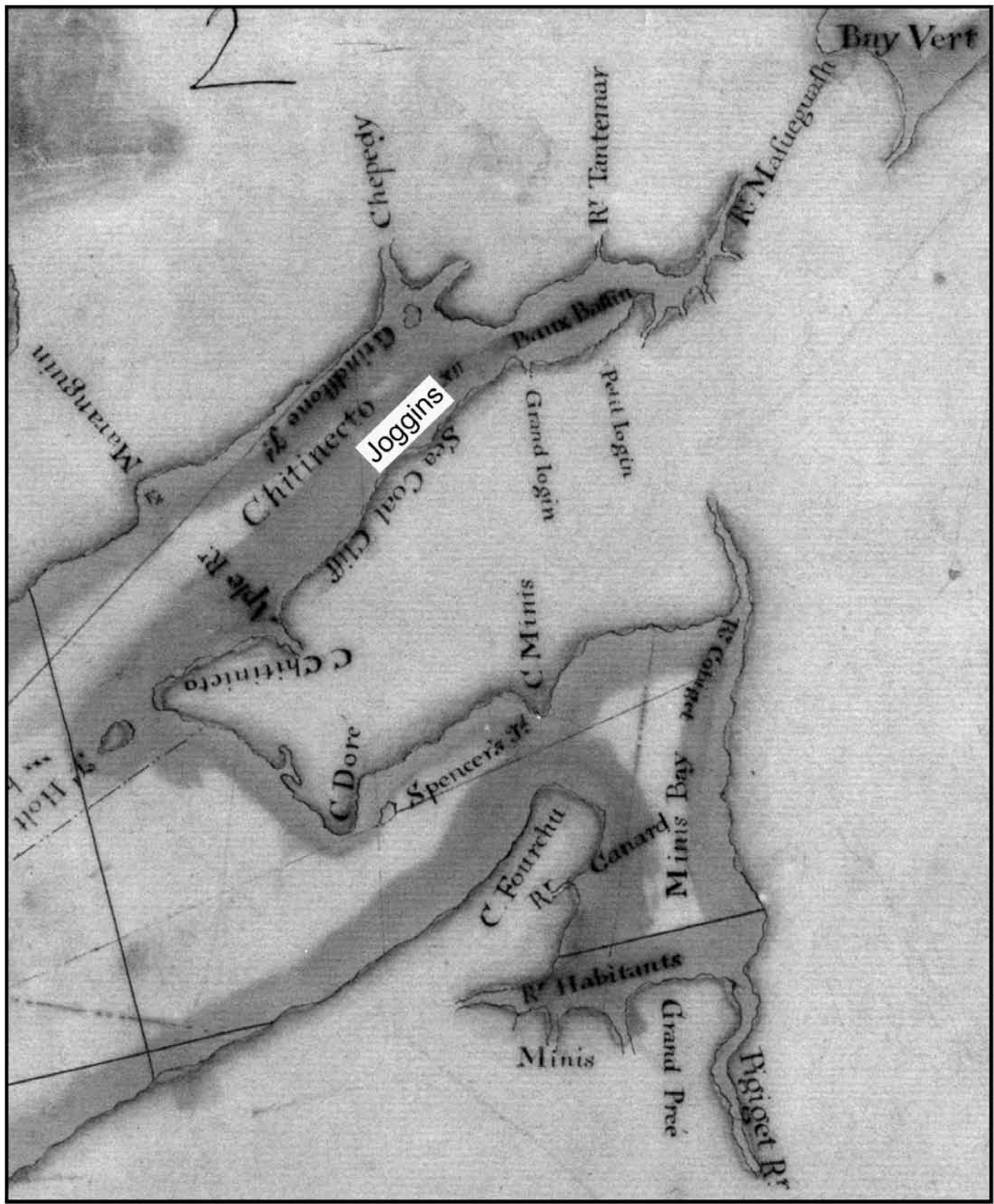

Fig. 8. Portion of Thomas Durell's chart of Nova Scotia (1736) showing the "Sea Coal Cliff" and the former location of Cope's wharf at Grand Jogin (=Gran'choggin of Hale 1731), positioned at present-day Downing Cove (see Fig. 1). The location of the coal-bearing cliffs at present-day Joggins is also shown. Courtesy of the National Archives, Kew. 


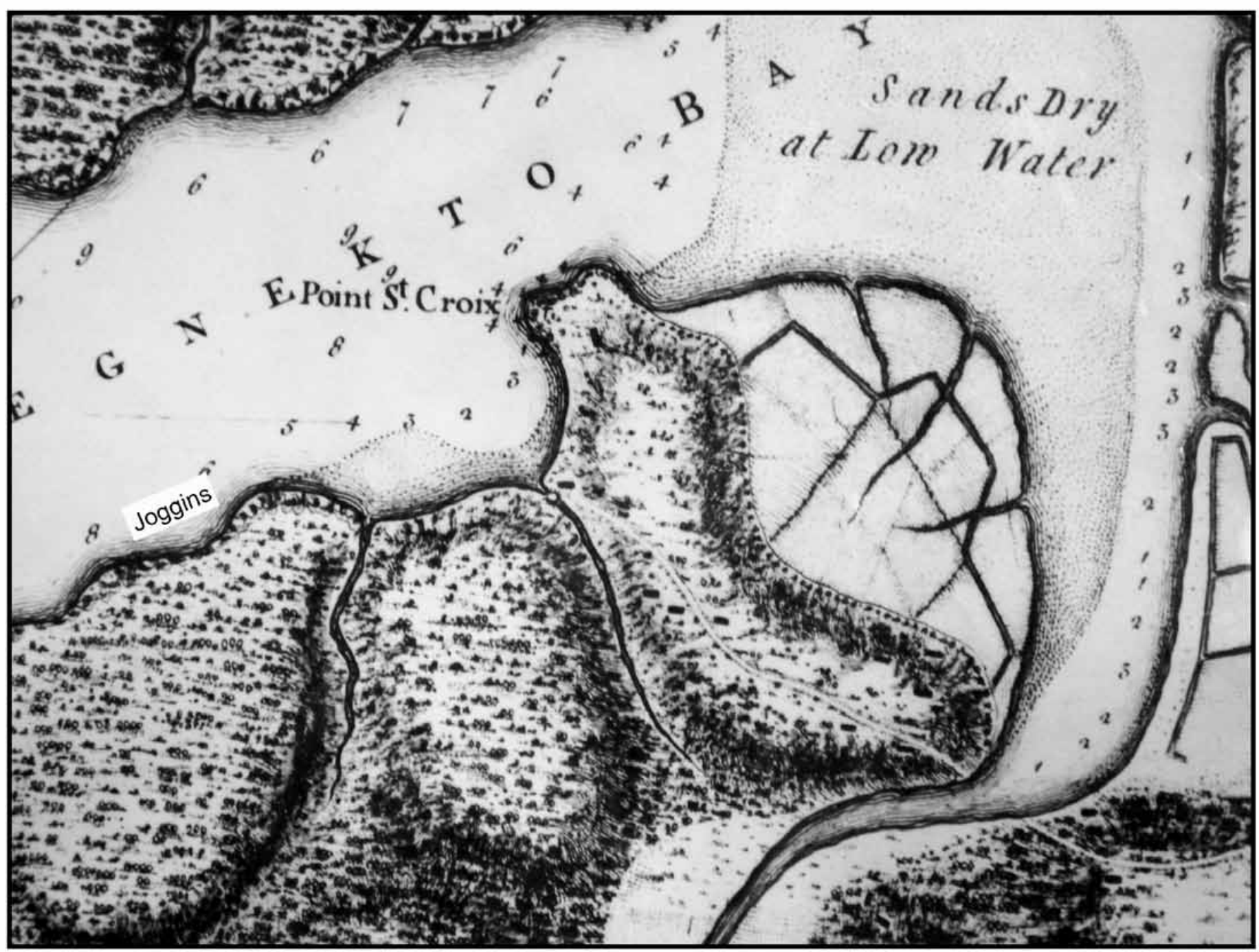

Fig. 9. Portion of a map of Chignecto Bay prepared by Jefferys (1755b) showing the mill (circular feature) at Mill Creek served by a track, but with no allusion to coal mining activity. Coal mining ceased at Joggins from 1750-1756. The location of the coal-bearing cliffs at present-day Joggins is shown. Courtesy of the Ralph Pickard Bell Library, Mount Allison University.

(1713-1776) instructed Lieutenant Colonel Charles Lawrence (1709-1760) to establish a fortified position in Beaubassin. After several clashes with Acadians led by Abbé Le Loutre (1709-1772), Lawrence erected Fort Lawrence on the eastern side of the Missaguash River. In an early phase of the conflict, Le Loutre ordered the burning of the villages of Beaubassin, including Rivère des Hébert, Minoudy and Les Planches, and demanded that Acadian populations draw back to position west of the Missaguash River. There, three French fortresses were established, a forward position, Fort Beauséjour, and satellite sites at Fort Gaspereaux and Fort Menagoueche (Clark 1968). Skirmishes continued between Acadian and British militia until the Grand Dérangement of 1755 . During this turbulent period, mining activity must have more or less ceased at Joggins as Acadian populations were entirely displaced to the north of the site.

Meanwhile, the British settlers who were pouring into Halifax were well informed about the important coal resources that lay on the Bay of Fundy. On 17 July 1750, John Salusbury
(1707-1762), a member of the Nova Scotia Council (now based in Halifax), having heard reports of "shaly rocks on the sea shore with very strong veins of coal” (Rompkey 1982, p. 88), petitioned Governor Cornwallis to open a colliery at Joggins (Rompkey 1982, p. 190). A year later, on 24 June 1751, Joshua Mauger (1725-1788), a wealthy merchant, was in Halifax to press for a license to work coal in the same area (W.P. Bell 1961, p. 161). However, the Board of Trade and Plantations discouraged both these ventures, fearing they would harm British imports from Newcastle, England. Nevertheless, although unexploited, the coal measures at Joggins continued to be alluded to in various publications. In his survey of the state of the British Colonies in North America, Douglass (1755) noted their occurrence and later that year, Jefferys (1755a) prominently marked the "Coal Cliffs" on his map of Nova Scotia. His detailed map of "Shegnecto [Chignecto] Bay and the Circumjacent Country" produced in the same year shows the "Coal Cliffs" (Fig. 9) but makes no allusion to coal mines (Jefferys 1755b). 
Following the start of the Seven Years War with France, the strategic significance of the Joggins coal measures increased. In 1756, Charles Lawrence, who had subsequently risen to the position of Governor, wrote to the British Government for permission to reopen "the coal mines near Chignecto" to supply fuel to the three regiments fighting in the Bay of Fundy (Murdoch 1865, p. 330). Permission was granted and in September 1757 Captain John Knox, serving on a warship in the Bay of Fundy, recorded in his diary that "a command of miners and colliers from the troops, with a covering party of regulars and rangers, embarked this day ... for the coal-pits about sixteen miles from the fort, near the Joggen" (Knox et al. 1759, p. 70). There is some uncertainty about whether this is a genuine reference to Joggins, because Knox et al. (1759, p. 70) described the location of these coal-pits as lying "between the capes of D'Or and Checnecto", i.e. Cape D'Or and Cape Chignecto, which are forty kilometres southwest of presentday Joggins (Figs. 1 and 10). However, as there is no coal between these two headlands, Knox's probable intention was to locate the mines between Cape D'Or and the community of Checnecto in Beaubassin. This seems to be confirmed by the fact that the fort mentioned by Knox et al. (1759) was Fort Cumberland (formerly known as Fort Beauséjour), which had been captured from the French in 1755. According to a very detailed map produced by Charles Morris (Fig. 11), the British force appear to have opened their mine on either the Queen or Joggins seams about a third of a mile south of the original

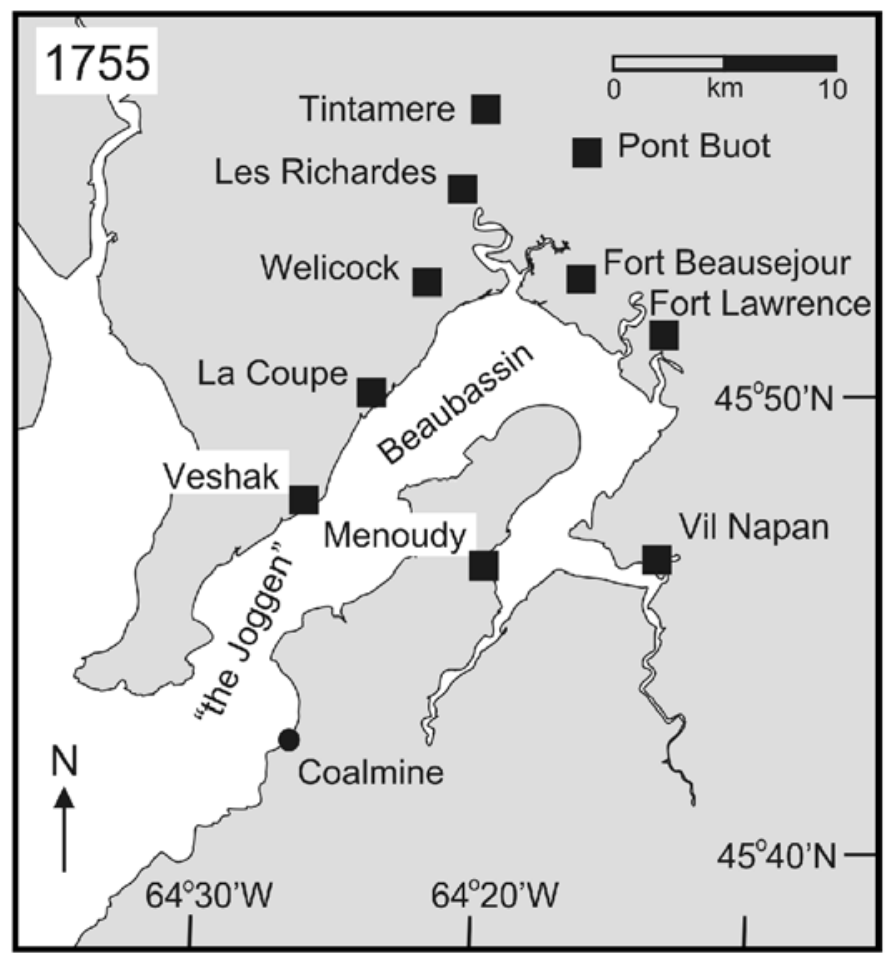

Fig. 10. Map of Beaubassin around 1755 at the time of the Grand Dérangement. Settlements, as in Clark (1968), are shown by black squares, and the narrow mouth of Beaubassin is labeled "the Joggen", as in Knox et al. (1759).
Acadian workings on the Fundy or Forty Brine seams (Morris 1761). Perhaps the decision to relocate the workings suggests that the original Acadian mines were already worked to a deep level at the time of British acquisition.

\section{COAL MINES AFTER BRITISH RESETTLEMENT (1760-1835)}

Following the end of the Seven Years War, coal mining may have temporarily ceased at Joggins. Although Charles Morris highlighted the "coal mines" as one of the assets available for the waves of New England colonists settling in the newly established townships of Sackville, Amherst, and Cumberland on Chignecto Bay (Morris 1761), mining operations do not appear to have recommenced after the militia disbanded. This seems have been the result of the continued policy of active suppression promoted by the Lords of Trade, who were concerned that local coal production might harm British exports to the Colonies (Clark 1968).

In addition, from 1764-1824, the land that included Joggins was granted to Joseph Des Barres (1721-1824). An absentee landlord who was at various times governor of Cape Breton (1784-1805) and Prince Edward Island (1805-1813), Des Barres had little interest in developing the coal resources on his property. Reflecting this change in land use, the "Coal Cliffs", which had been prominently marked on maps from 17021755 , more or less disappeared from those prepared between 1776 and 1838 (Holland and Pawnall 1776; Cary 1807; Purdy 1814; Bradford 1838). Even when Des Barres commissioned a detailed set of maps of Chignecto, prepared by Acadians who had resettled on his property, there was no mention at all of the former coal mines. The only annotation to these charts refers to the "Shedd [i.e. shad] Fisheries" located at Mill Creek (Des Barres 1777). One exception might be a map (Montresor 1768), which curiously shows a settlement called "Joggin" located just east of the mouth of River Hebert at the site of present-day Lower Maccan (it also occurs on Cary's 1807 map). The significance of this label is unknown, but it may reflect a community of Acadian coal miners who had returned to their native lands and established Joggins at a new location. Lower Maccan is positioned on the inland extension of the Joggins coal measures.

There are also other hints that sporadic mining activity continued during this period. Renewed interest in coal may have been triggered by the arrival, in 1772, of large numbers of settlers from Yorkshire, England, an established coal-mining area (Trueman 1902). In 1776, Fort Cumberland was refortified as a defence against insurgents from the American Revolutionary War (Clarke 1999), and there are cryptic references to the British garrison there extracting coal "in considerable quantity" at irregular intervals up until the War of 1812 (Martell 1945). Because the British military mined mainly the Joggins Seam, this became known as the "King's Vein" in honour of King George III (Gesner 1836). However, extraction evidently did not occur on a commercial basis: a summary of mineral 


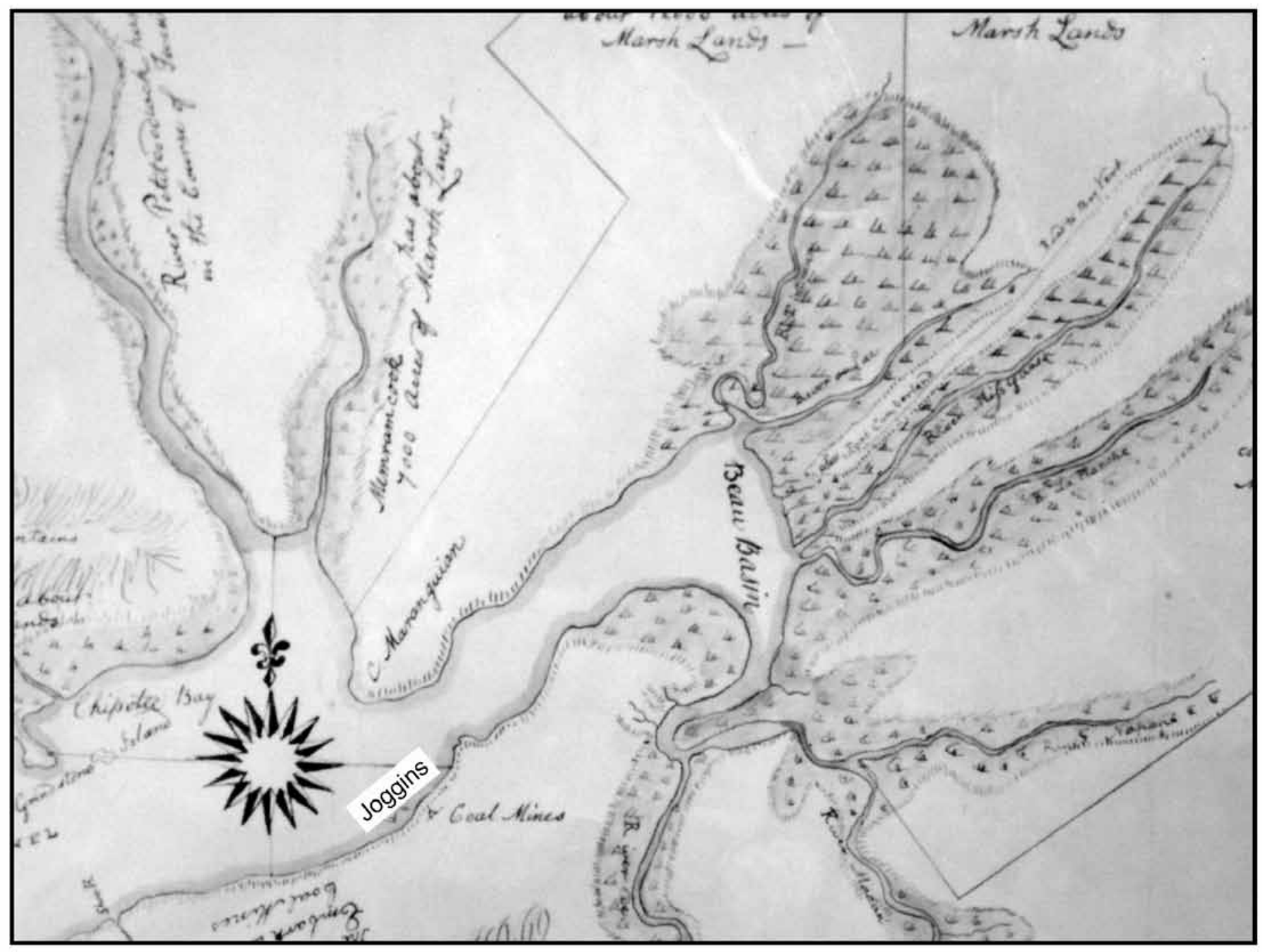

Fig. 11. Portion of a map of the Chignecto area drawn by Morris (1761) and showing the new settlements of Cumberland, Amherst and Sackville. If accurately placed, the location of the "coal mines" seem to suggest that coal was being mined to the southwest of Coal Mine Point, i.e. the Joggins and Queen seams. The location of the coal-bearing cliffs at present-day Joggins is shown. Courtesy of the Ralph Pickard Bell Library, Mount Allison University.

wealth of Chignecto (Hollingsworth 1787, p. 692) noted that the "pit coal is of inferior quality abounding with sulphur" but stated that in the future it might "become useful to the province, as an article of export". Nevertheless, at this time, rumour had it that the nascent United States, which was dependent on Nova Scotia for coal, was eager to annex these resources for its own exclusive use (Gifford 1817, p. 974).

In the early nineteenth century, the map by Cary (1807) marks "Les Mines" over the inland extension of the Joggins coal measures at River Hebert, perhaps suggesting the existence there of small dispersed mines. However, a British Government Report of 1814 bemoaned the fact that though there were many coal mines in Cumberland County, "none were being worked, except a small one near Cobequid, from which the neighbouring settlers get the chief part of their fuel" (Morse et al. 1814, p. 90). So it is likely that Cary's annotation simply marked the disused remnants of old Acadian coal mines, or even copper mines. Although Samuel McCully did open a coal mine at Joggins in 1819 with the intention of supplying coal to Saint John, New Brunswick, competition with British exporters drove him out of business in 1821, having shipped only 550 chaldrons (Martell 1945). No reference to active coal workings is made on a detailed map drawn up in 1824 (Anon. 1824).

In 1827, the General Mining Association of Britain became "lessees of all the mines and minerals of every description in the province of Nova Scotia Proper" (Martin 1834, p. 105). The Association decided to concentrate initial efforts at Pictou and Sydney, and so suppressed attempts to mine coal at Joggins. This led Abraham Gesner (1836) to complain bitterly about the lost potential of the Joggins coal field. Despite official discouragement, bootleg operations sprang up at Joggins, and Gesner (1836) reported mining activity there by a group of Cornish miners working small "openings" here and there, while T. 
Smith (1836) referred to the "Cumberland coal mines" near the Joggins. The General Mining Association did not open its first coal mine at Joggins until 1847 (Gesner 1849), and even then only on a comparatively small scale.

\section{EARLY HISTORY OF GRINDSTONE QUARRYING} (1731-1835)

A second major industry that became established along the Joggins Section was the manufacture of grindstones (Fig. 12). Grindstones were used in the production of edged tools, including knives, axes, saws, scythes, files, hammers and chisels, as well as for hogging off cast iron (Snowdon 1972). Grindstone quarrying was a feature of Chignecto Bay from the beginning of the eighteenth century and possibly earlier (Eardley-Wilmot 1927). Initially the centre of operations was on Mill Island (Blackmore 1714-1715; Fig. 5), close to the New Brunswick coast, which according to a British report for 1720-1721, had "a good quarry of soft stone ... [that] cuts in layers of four or six inches" (Murdoch 1865, p. 396). By 1731, the island's name had changed to Grindstone Island (Hale 1731), reflecting a change in the dominant market for this stone from milling grain to grinding metal. However, the names Mill(e) Island and Grindstone Island were used interchangeably until the mid-eighteenth century (Morris 1748, 1761; Jefferys 1755a).

Grindstone manufacture along the Joggins Section, like coal mining, may have commenced in the early eighteenth century, although there are no clear records until after the Grand Dérangement. Minudie (Minoudy), an important grindstone centre near Joggins, is labelled on the map by Franquelin (1686; Fig. 2), and there are indications that quarrying may have begun at Lower Cove well before 1755 (Snowdon 1972). For example, when Des Barres purchased the Chignecto Peninsula in 1764, he discovered that some Acadians had returned to their former lands as squatters and were re-establishing an earlier practice of grindstone quarrying. Through the late eighteenth

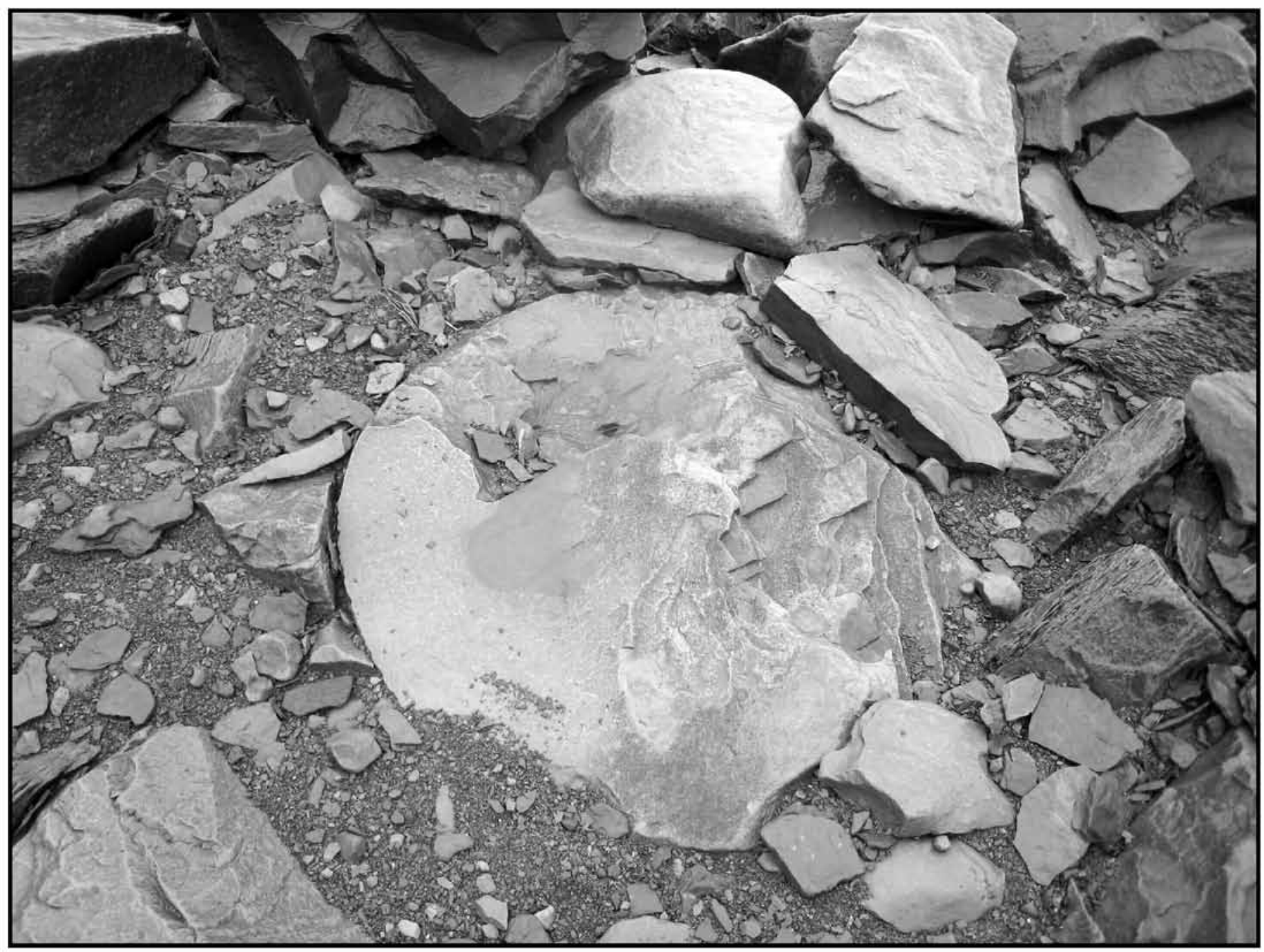

Fig. 12. One of the many grindstones (ca. $1 \mathrm{~m}$ diameter) scattered over the beach at Lower Cove. Flawed grindstones were simply abandoned on the shore. 
century, Des Barres informally leased the coastal ledges of rock to these Acadian settlers, who quarried grindstones on a cooperative basis (Eardley-Wilmot 1927).

In the early nineteenth century, the best of these quarries, known as Bank Quarry, was located two miles north of the Joggins coal-bearing succession, at present-day Lower Cove (Fig. 1), and operated by Joseph Read and John Seaman from 1815-1830. This quarry produced the famous "Nova Scotia blue-grit", a 44-foot thick, compact, fine-grained, ironstained sandstone of late Namurian (Yeadonian) age (Calder et al. 2005), which was exported to markets as far afield as Boston, Massachusetts (Gesner 1849). Read and Seaman operated a second grindstone quarry on the eastern side of the Maringouin Peninsula, New Brunswick, at present-day Rockport on the north shore of Chignecto Bay (then known as North Joggins), while others sprang up around Sackville, Hopewell, and Dorchester (Fig. 13; Eardley-Wilmot 1927). Between 1800 and 1830, an enterprising storekeeper named William Harper periodically visited these quarries in his schooner, The Weasel, exchanging food, clothing and other commodities for grindstones, which he sold at Passamaquoddy near the disputed border with the United States (Eardley-Wilmot 1927). The earliest surviving receipt for the purchase of grindstones at Rockport dates from 21 November 1806 (Snowdon 1972).

In 1825 , following Des Barres's death, John Seaman's youngest brother, Amos Seaman (1788-1864), was appointed by the family of the deceased to collect rents on the quarries (MacKensie 1976). Then from 1826-1834, Amos Seaman, together with his business partner William Fowler, acted as property managers, responsible for leasing the quarries on the Des Barres land, before purchasing the entire 7000-acre estate for themselves in 1834. The first year of Seaman and Fowler's operation in 1834 saw grindstone exports to the United States triple to 30671 (Anon. 1850). Many of Seaman's quarries relied on the high tides of the Bay of Fundy because stone was extracted from below the high water level, secured to boats, and then allowed to float off the seabed as the tide rose (Gesner 1849), before being transported to a pre-prepared work bed. The boats were of a type used in the local shad fishery (adapted with a wider beam) and were called "Grindstone Boats" or "Joggins Boats" (Snowdon 1972). This work could only be undertaken during the summer months, when hundreds of seasonal employees set up temporary shelters along the cliff-tops (Gesner 1836). It was probably in one such "rough building" where, in 1835, the teenaged William Dawson (1820-1899), later pioneer interpreter of the Joggins Section and one of Canada's premier Victorian scientists, stayed during his first visit to Joggins (Dawson 1901).

\section{ORIGIN, EVOLUTION AND SIGNIFICANCE OF THE TERM JOGGINS}

In addition to providing a critical review of the history of coal mining and stone quarrying, the above discussion sheds new light on the origin and evolution of the name "Joggins".

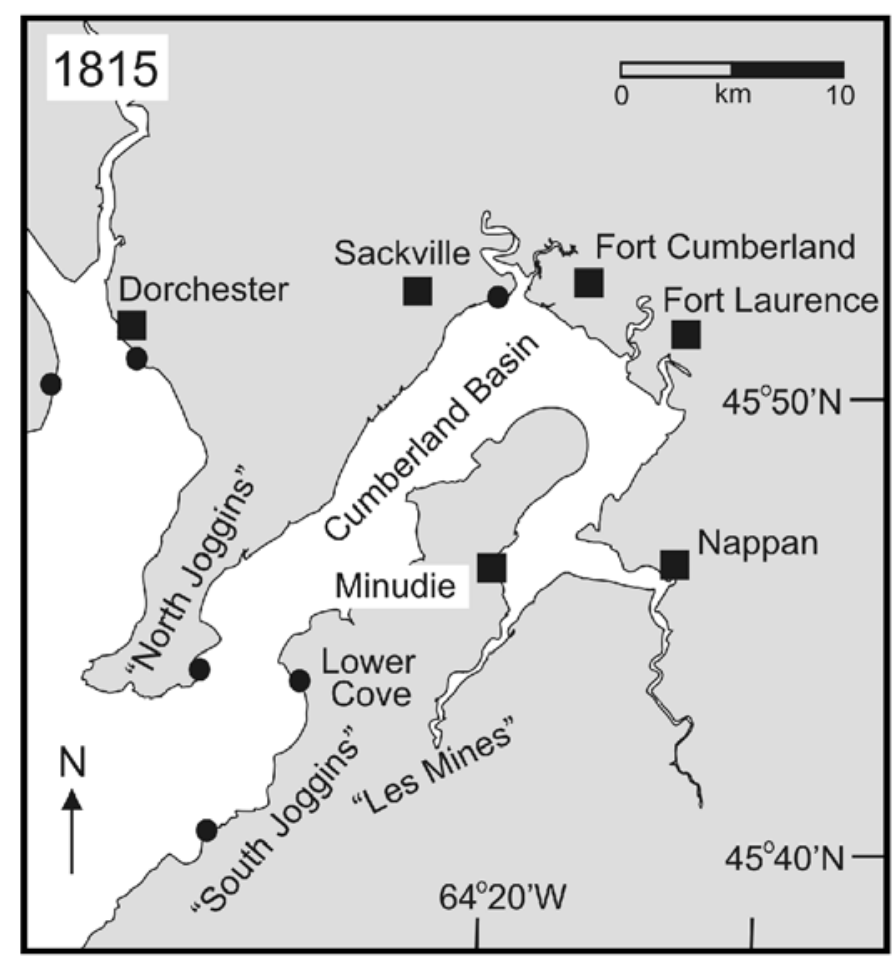

Fig. 13. Map of upper Chignecto Bay around the time that William Harper was trading grindstones on his schooner, The Weasel, from 1800-1830.

The etymology of the name has been subject to debate since 1842, when a local resident duped Charles Lyell into believing that it referred to the way in which the cliffs "jog in and jog out" (Lyell 1845, p. 194). Although Joggins is unequivocally of Mi'kmaq origin, it seems to have entered Acadian usage sometime prior to the start of Major Henry Cope's coal mining venture in 1731. As already discussed, Cope constructed a wharf and coal depot seven miles north of the coal mine, positioned at the sheltered mouth of a creek "call'd Gran'choggin" (Hale 1731, p. 230). This arrangement is shown on two maps dating from the period. On the first map, Mitchell and Amhurst (1735) label the coast adjacent to present-day Joggins as "Coal Clifts" while north of present-day Boss Point they mark the wharf and coal depot as "Grand Nyjagon". On the second map, Durell (1736) similarly depicts the "Sea Coal Cliffs", and north of Boss Point, marks "Grand Jogin" and little further up the bay, "Petit Jogin” (Fig. 8).

Comparison of Mitchell and Amhurst (1735) and Durell (1736) with recent maps of the coastline clearly shows that Cope's wharf at Gran'choggin was located at present-day Downing Cove, with Petit Jogin located at Mill Creek (Figs. 1 and 8). If a nautical course is plotted that gives Boss Point adequate clearance, the distance between the main coal outcrops at present-day Joggins and Downing Cove is seven miles. This is the same distance that Hale (1731) reported from the coal mine to Gran'choggin. In addition, topography of Downing Cove matches Hale's description of Gran'choggin as sheltered, fed by a creek (now unnamed), and comprising a wide tidal flat at low tide (Fig. 14). Furthermore, this location is consistent with the 


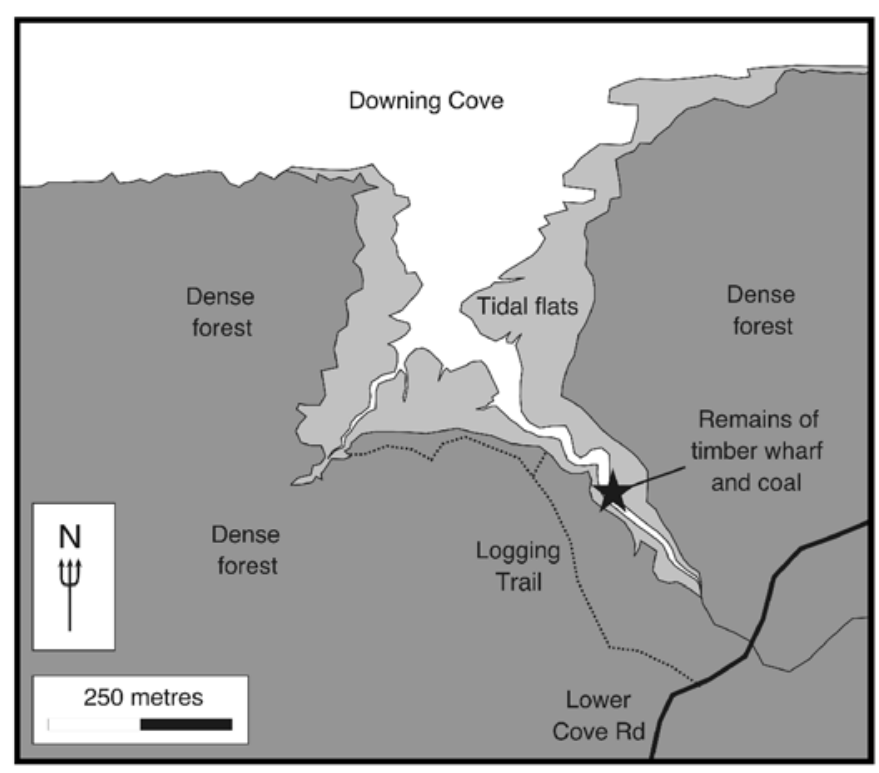

Fig. 14. Map of Downing Cove showing the tidal creek formerly known as “Gran'choggin”. Captain Andrew Belcher and later Major Henry Cope used this site as a coal depot from before 1711 until 1732. The tidal flats (light grey) are depicted at around mid-tide while forests are shown as dark grey.

meaning of the Mi'kmaq words most similar to Gran'choggin: choggin may refer to a brook or creek (Tooker 1911) while chegoggin is thought to mean "a place of fish weirs" (Hamilton 1978, p. 339). A third word, chegoggins, which means "great encampment" (Calder 2006) seems less relevant to this geographic context but could have derived from the locality if an encampment had sprung up around the fishery.

A field visit to Downing Cove, undertaken on 16 November 2008 , lends additional support to the hypothesis that the Gran'choggin coal depot was located at Downing Cove. A large sinuous creek extends from the southeast corner of the cove and winds inland for about $400 \mathrm{~m}$ (Fig. 15). The creek maintains a steady width of about $20-25 \mathrm{~m}$ and has a bankful depth at high tide of approximately 4-6 m. An interview during the visit with Wayne Hoeg, whose family has owned the property at Downing Cove for five generations, since 1870, indicates that in the early twentieth century schooners navigated up the creek to a sheltered wharf. The remains of a timber wharf, rotted down to low water mark, occur about three quarters of the way up the channel. Although this wharf is likely a nineteenth century structure, fragments of coal occur on the adjacent banks of the creek. There are no outcrops of coal in Downing Cove, only beds of red sandstone and conglomerate, so the coal must have been brought to the site from another locality. It is possible that the coal fragments are remnants from coal depot that existed here until 1732, or derived from a later stockpile.

The combination of evidence strongly suggests that the place name of Joggins is derived from a Mi'kmaq word that originally referred to the fishery at Downing Cove. This is especially credible given that a large shad fishery is located on early maps of this region (Des Barres 1777). The term, Joggins, was only later applied to the "Coal Cliffs" to the south by its association with coal mining. In addition, given that the coal mines were initially operated by Acadians, it seems likely that the term Gran'choggin arose either as a fusion of the French grand (big) and the Mi'kmaq choggin (brook or creek), or as a partial French translation of chegoggins, meaning "great encampment". The former possibility is considered to be the more likely given that the adjacent bay at Mill Creek was named "Petit Jogin" (Durell 1736), and this may further imply that Joggins was used by the Mi'kmaq in a generalized sense for fisheries on that stretch of coast.

In its early written manifestations, the term "Joggins" was highly unstable, being variously rendered as Gran'choggin (Hale 1731), Grandnajagan (Moll 1732), Grand Nyjagon (Mitchell and Amhurst 1735), Grand Nyagan (1736), Grand Jogin(Durell 1736) and Grand Nigagan(Anon. 1753). However, from the mid-eighteenth century until the early nineteenth century, usage seems to have stabilized as "the Joggen" with the meaning broadened to refer to the narrow, rocky, upper reaches of Chignecto Bay (Fig. 10). Hence Knox et al. (1759, p. 57) could write that, "We sailed through the Joggen, and soon after came to anchor in the Bason, called by the French, with much propriety, Beau Bassin". Knox further noted that the coal mines were only "near the Joggen", thus implying that they were not at the Joggen.

The shift in meaning of "Joggins" from the fishery at Downing Cove to the narrow straits at the mouth of the upper part of Chignecto Bay may be related to the rise of the grindstone industry. In the nineteenth century the term "South Joggins" entered widespread usage for the shoreline from Mill Creek to Ragged Reef (Anon. 1824; Brown and Smith 1829; Jackson and Alger 1829; Emmons 1836; Gesner 1836). As Calder (2006) has noted, this term arose to distinguish the two areas of grindstone quarrying, which lay either side of Chignecto Bay; the opposite shore located on the Maringouin Peninsula being called "North Joggins" (Fig. 13). The first usage of "North Joggins" dates from 1774 (Milner 1907). Although there is no reference to "South Joggins" until 1824 , likely the two terms co-existed during the latter part of the eighteenth century. Hence, when Knox sailed through "the Joggen" in 1757 he may have been referring to the two areas of grindstone manufacture flanking the straits of Beaubassin.

In the early nineteenth century, usage of "the Joggin(s)" remained commonplace (Anon. 1824; Jackson and Alger 1829; Bouchette 1831; T. Smith 1836; Emmons 1836), but in addition terms like "the Joggen Shore" (Brown and Smith 1829) and "the Joggin(s) Shore" (Gesner 1836) were introduced. This apparent need to emphasize the shoreline implies that the term, "the Joggin(s)" was still being used as a descriptor for the straits in the upper reaches of Chignecto Bay as late as the 1830s. This may explain why William Logan's famous $20 \mathrm{~km}$ long section from Mill Cove to Shulie (Logan 1845) became known as the "Joggins Section" (Rygel and Shipley 2005) despite the fact that at the time Lower Cove was the only sizeable community on an otherwise sparsely populated coastline (Gesner 1836, 


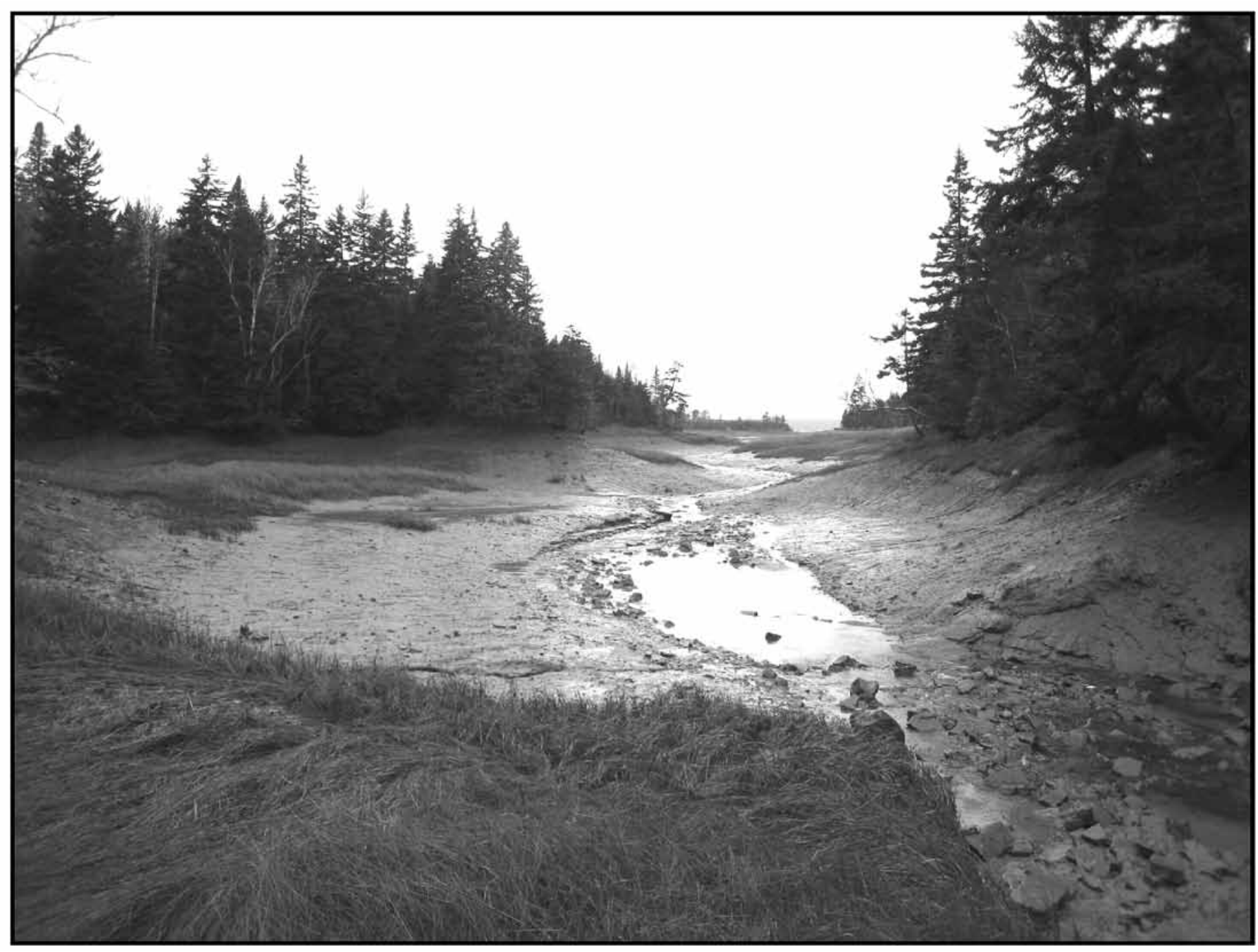

Fig. 15. The creek formerly named Gran'choggin at present-day Downing Cove, looking out to sea at low tide. Schooners navigated half a mile up this creek to a sheltered wharf to load coal at Cope's depot in 1731-1732.

1849). The specific connection between the term "Joggins" and the coal measures was finally re-established in 1847 when the General Mining Association opened its first coal mine (Gesner 1849). This acted as a nucleus for the formation of the first community at the present site, named "Joggins Mines".

\section{CONCLUSIONS}

1. Coal was first observed at Joggins by Franquelin in 1686, with Acadian coal mines springing up by 1701, or thereabouts, and supplying markets as far afield as Boston in New England.

2. A brief interval of British coal mining from 1731-1732 ended in disaster when the Mi'kMaq destroyed the site. This operation hinged on the construction of a wharf at Gran'choggin (present day Downing Cove), which later gave its name to the Joggins "Coal Clifts" ("Adventurer's Clifts") by association.
3. After the Grand Dérangement, British forces engaged in the Seven Years War briefly reopened the coal mines in 1756, but thereafter the Lords of Trade suppressed all coal mining until the General Mining Association redeveloped the site in 1847.

4. During this lull, the grindstone industry boomed, filling the gap in the local economy. The main quarries were located at Lower Cove, however, others sprung up on the Maringuoin Peninsula, and the two opposing shores became known as the North and South Joggins.

\section{ACKNOWLEDGEMENTS}

I gratefully acknowledge receipt of a Leverhulme Early Career Fellowship held at the University of Bristol. Mike Rygel (Potsdam, New York) kindly provided the images that form the basis of Figure 1. Diane Buhay (University of New Brunswick Library) and Randy Miller (New Brunswick Museum) helped 
track down some of the obscure documents used in this study. Elisabeth Millar (Mount Allison University) directed me to several key maps and manuscripts. Paul Bogaard (Mount Allison University) directed me to many more maps, kindly provided the image used in Figure 3, and offered detailed criticism that greatly developed the manuscript. This paper additionally benefited from the constructive criticism of Regis Brun (Moncton), Chris Cleal (National Museum of Wales), Martin Gibling (Dalhousie University), and the meticulous editorial work of Rob Fensome (Geological Survey of Canada, Atlantic).

\section{REFERENCES}

Anon. 1749. A description of Nova Scotia. The London Magazine, or The Gentleman's Monthly Intelligencer, 18, pp. 181-184.

Anon. 1753. Accadie. Bibliothèque nationale de France. Accession Number: Port 133 Div 10 Piece 5D.

Anon. 1824. Chart of the Bay of Fundy compiled from various manuscript documents in the Hydrographical Office of the Admiralty. Scale 1 inch: 3.3 miles. Public Records Office, Kew, UK. Accession number MR1/789.

Anon. 1850. Executive documents printed by the order of the United States, Volume 4, pp. 87-95.

Anon. 1888. First report of the Secretary of the Province of Quebec, 1886-1887. Herald Printing House, Halifax, 270 p.

Aston, R.L. 1999. The legal, engineering, environmental and social perspectives of surface mining law and reclamation by landfilling: getting maximum yield from surface mines. Imperial College Press, London, $512 \mathrm{p}$.

Baker, C.H.C., and Baker, M.I. 1949. The life and circumstances of James Brydges: first Duke of Chandos. Clarendon Press, Oxford, 493 p.

Bell, W.A. 1965. Lower Cretaceous floras of western Canada. Geological Survey of Canada Memoir 285, 331 p.

Bell, W.P. 1961. The "foreign protestants" and the settlement of Nova Scotia: the history of a piece of arrested British colonial policy in the Eighteenth Century. University of Toronto Press, $673 \mathrm{p}$.

Bird, J.B. 1955. Settlement patterns in Maritime Canada: 1687-1786. Geographical Review 45, pp. 385-404. doi:10.2307/211811

Blackmore, N. 1714-1715. Plaine chart of the province of Nova Scotia and l'Acadia. Public Records Office, Kew, UK. Accession Number: CO 700/NOVA SCOTIA4.

Bouchette, J. 1831. The British dominions in North America, volume 2. Colburn and Bentley, London, $322 \mathrm{p}$.

Bradford, T.G. 1838. Map of Lower Canada and New Brunswick. (inset) Nova Scotia. G.W. Boynton Publishers, London.

Braybrooke, R. 1825. Memoirs of Samuel Pepys, Esq., F.R.S., Secretary to the Admiralty in the reigns of Charles II and James II. Henry Colbourn, London.

Bridenbaugh, C. 2007. Cities in the wilderness: the first cen- tury of urban life in America 1625-1742. Alfred Knopf, New York, $516 \mathrm{p}$.

Brown, R., and Smith, R. 1829. Geology and mineralogy, Volume 2. In An historical and statistical account of Nova Scotia. Edited by T.C. Haliburton, Joseph Howe, Halifax, pp. 414-453.

Calder, J.H. 2006 "Coal Age Galapagos": Joggins and the lions of Nineteenth Century geology. Atlantic Geology 42, pp. 37-51.

Calder, J.H., Rygel, M.C., Ryan, R.J., Falcon-Lang, H.J., and Hebert, B.L. 2005. Stratigraphy and sedimentology of Pennsylvanian red beds near Joggins, Nova Scotia: The Little River Formation with redefinition of the Joggins Formation. Atlantic Geology 41, pp. 143-167.

Cary, J. 1807. A new map of Nova Scotia, Newfoundland \&c. from the latest authorities. J. Cary, Engraver \& Map-seller, London.

Charbonneau, A. 1972. Un Cartographe de Québec au XVIIe siècie: Jean Baptiste Louis Franquelin. These de maitrise, Departement 'histoire, Universite de Montreal.

Clarke, A.H. 1968. Acadia: The geography of early Nova Scotia to 1760 . University of Winconsin Press, Madison, $450 \mathrm{p}$.

Clark, E. 1999. The seige of Fort Cumberland 1776. McGillQueens Press, Montreal, 336 p.

Copeland, M.J. 1958. Coalfields, west half Cumberland County, Nova Scotia. Geological Survey of Canada, Memoir 298, 89 p.

Cornell, J.F. 1983. From creation to evolution: Sir William Dawson and the idea of design in the Nineteenth Century. Journal of the History of Biology 16, pp. 137-170. doi:10.1007/BF00186678

Dawson, J.W. 1868. Acadian geology or the geology of Nova Scotia, New Brunswick and Prince Edward Island. 2nd edition. Oliver and Boyd, Edinburgh, 694 p.

Dawson, J.W. 1901. Fifty years of work in Canada, scientific and educational. Ballantyne, Hanson \& Co., Montreal, 308 p.

Des Barres, J.W.F. 1777. Chart of Chignecto Bay. National Maritime Museum, Greenwich, London. Accession number: K0442 - HNS 17A.

Douglass, R. 1755. A summary, historical and political of the first planting, progressive improvement and present state of the British Settlements in North- America. Volume 1. Baldwin, Boston, pp. 332.

Dunn, T.S., Savage, J., and Yeandle, L. 1996. The Journal of John Winthrop, 1630-1649. Harvard University Press, 374 p.

Durell, T. 1736. A chart of the sea coast of Nova Scotia, Accadia and Cape Breton. Public Records Office, Kew, UK. Accession number: CO 700/NOVA SCOTIA12.

Eardley-Wilmot, V.L. 1927. Abrasives, part I, siliceous abrasives. Mines Branch, Canada Department of Mines, Publication, Number 673, pp. 6-18.

Emmons, E. 1836. Notice of a scientific expedition. American Journal of Arts and Sciences 30, pp. 330-354.

Falcon-Lang, H.J. 2006. A history of research at the Joggins 
Fossil Cliffs, the world's finest Pennsylvanian section. Proceedings of the Geologists' Association 117, pp. 377-392.

Falcon-Lang, H.J., and Calder, J.H. 2005. Sir William Dawson (1820-1899), a very modern palaeobotanist. Atlantic Geology 41, pp. 103-114.

Falcon-Lang, H.J., Benton, M.J., Braddy, S.J., and Davies, S.J. 2006. The Pennsylvanian tropical biome reconstructed from the Joggins Formation of Canada. Journal of the Geological Society, London 163, pp. 561-576. doi:10.1144/0016764905-063

Fergusson, C.B. 1955. Durells in 18th Century Canadian history. The Dalhousie Review 35, pp. 16-30.

Franquelin, J-B. 1686. Chignitou: nommé depuis par les françois Beaubassin. Archives du Hydrographique de la Marine, Paris.

Franquelin, J-B. 1702. Carte de l'Acadie Contenant tous les portsports, havres, sondes \& mouillages qui font le long de fes cotes, les bois, montagnes, lacs, \& marais qui font dans la profon deur de fes terres \& touttes les rivierres qui en descendent. Bibliothèque nationale de France. Accession Number: Port 132 Div 132 Piece 5.

Ganong, W.F. 1930. The Cadillac memoir on Acadia of 1692. Collections of the New Brunswick Historical Society 8, pp. 89-91.

Gesner, A. 1836. Remarks on the geology and mineralogy of Nova Scotia. Gossip \& Coade, Halifax, 339 p.

Gesner, A. 1849. The industrial resources of Nova Scotia. A.C. MacKinlay, Halifax, 341 p.

Gifford, C.H. 1817. History of the wars occasioned by the French Revolution. Lewis, London, 974 p.

Goudge, M.G. 1945: Joggins-River Hebert coal district (a review). Nova Scotia Department of Mines, Annual Report 1944, pp. 152-182.

Grant, W.L. 1907. Voyages of Samuel de Champlain, 16041618: with a map and two plans. Charles Scribner, New York, $377 \mathrm{p}$.

Hale, R. 1731. Journal of a voyage to Nova Scotia made in 1731 by Robert Hale of Beverly. Reprinted in the Historical Collections of the Essex Institute 42, pp. 217-243 (for 1906).

Hamilton, W.B. 1978. The Macmillan book of Canadian place names. Macmillan, Toronto, $340 \mathrm{p}$.

Holland, M, and Pownall, G. 1776. A general map of the northern British colonies in America, which comprehends the province of Quebec, the Government of Newfoundland, Nova-Scotia, New-England and New-York. Admiralty and Board of Trade. Robert Sayer \& Jonathan Bennett Publishers, Fleet Street, London.

Hollingsworth, S. 1787. The present state of Nova Scotia with a brief account of Canada, and the British islands on the coast of North America. Creech, Edinburgh, 1055 p.

Innes, H.A. 1977. Select documents in Canadian economic history. Porcupine Press, 1427 p.

Jackson, C.T., and Alger, F. 1829. A description of the mineralogy and geology of a part of Nova Scotia. American Journal of Science and Arts 15, pp. 132-160.
Jefferys, T. 1755a. A new map of Nova Scotia and Cape Britain, with the adjacent parts of New England and Canada, composed from a great number of actual surveys. St. Martins Lane, Charing Cross, London.

Jefferys, T. 1755b. A large and particular plan of Shegnekto Bay and the cicumjacent country, with the forts and settlements of the French 'till dispossess'd by the English in June 1755. Drawn by an officer. Ralph Pickard Bell Library, Mount Allison University. Accession Number: G 3432.C55 1755 J4 $1970 \mathrm{z}$.

Knox, J., George, A.D., Amherst, J., Amherst, W., Johnson, W., and Murray, J. 1759. An historical journal of the campaigns in North America, Volume 1. Reprinted by the Champlain Society, Toronto, $512 \mathrm{p}$.

Little, O. 1748. The state of trade in the northern colonies considered with an account of their produce, and a particular description of Nova Scotia. Woodfall, Charing Cross, London, $88 \mathrm{p}$.

Logan, W.E. 1845. A section of the Nova Scotia coal measures as developed at Joggins on the Bay of Fundy, in descending order, from the neighbourhood of the west Ragged Reef to Minudie, reduced vertical thickness, Appendix W: Geological Survey, 1844-5. Journals of the Legislative Assembly of the Province of Canada 4, pp. 28-45.

Lyell, C. 1843. On the upright fossil-trees found at different levels in the coal strata of Cumberland, Nova Scotia. Proceedings of the Geological Society, London 4, pp. 176-178.

Lyell, C. 1845. Travels in North America, in the years 1841-2; with geological observations on the United States, Canada, and Nova Scotia. John Murray, London, 231 p.

Lyell, C. 1871. Elements of geology. New York, Harper, 940 p.

Mackensie, R. 1976. Seaman, Amos Peck. In Dictionary of Canadian Biography, Volume IX, 1861-1870. Edited by W.B. George, J. Hamelin, J., and F.G. Halpenny, University of Toronto Press, pp. 709-710.

MacMechan, A. 1900. A calendar of two letter-books and one commission-book in the possession of the Government of Nova Scotia, 1713-1741. Herald Printing House, Halifax, $270 \mathrm{p}$.

MacMechan, A. 1908. Original minutes of His Majesty's Council at Annapolis Royal, 1720-1739. McAlpine, Halifax, 220 p.

Martell, J.S. 1945. Early coal mining in Nova Scotia. Dalhousie Review 25, pp. 156-172.

Martin, R.M. 1834. The British Colonial Library, Volume 4. Bohn, London, $896 \mathrm{p}$.

Martin, G. 2003. Gesner's dream: the trials and triumphs of early mining in New Brunswick. Canadian Institute of Mining, Fredericton, 328 p.

Miller, R.F., and Buhay, D.N. 2007. Gesner's Museum of Natural History, an early Canadian Geological Collection. Geoscience Canada 34, pp. 37-48.

Milner, W.C. 1907. Records of Chignecto. Nova Scotia Historical Society, Halifax, 86 pp.

Mitchell, G., and Amhurst, E. 1735. A map of a Peninsula situ- 
ate in ye Bay of Fundy surveyed by order of the Honble. Laurence Armstrong, Esqr., Lieut. Governor. 2 pp. Public Records Office, Kew, UK. Accession number: MPG1 CO 217/39 folio 151.

Moll, H. 1717. A new map of Newfoundland, New Scotland, the isles of Breton, Anticoste, St. John's etc. together with the fishing bancks. John Nicholson, London.

Moll, H. 1720. A new map of the north parts of America claimed by France under y names of Louisiana, Mississippi, Canada and New France with y adjoining territories of England and Spain. Bibliothèque nationale de France, Paris. Accession number: Ge DD 2987 (8538) B.

Moll, H. 1730. A new and exact map of the dominions of the King of Great Britain on ye continent of North America containing Newfoundland, New Scotland, New England, New York, New Jersey, Pensilvania, Maryland, Virginia and Carolina. John Nicholson, London.

Moll, H. 1732. Atlas Minor. Thos. Bowles in St. Pauls Church Yard \& John Bowles at the Black Horse in Cornhill, London.

Montresor, J. 1768. Map of Nova Scotia, or Acadia; with the islands of Cape Breton and St John's. A. Dury Publisher, London.

Morris, C. 1748. Draught of the upper part of the Bay of Fundy: taken 1748 by order of the Hon.Paul Mascarene Esq., Lieut. Governor and Commander in Chief of His Majesty's Province of Nova Scotia, and at the request of His Excellency William Shirley Esq., Governor of His Majesty's province of the Massachusetts Bay in New England. Scale: 1:70,000. Ralph Pickard Bell Library, Mount Allison University. Accession Number: G 3432 .F8 1746 M^1970z.

Morris, C. 1761. A plan of the District of Chignecto. All the lands therein contain'd are ungranted except the townships of Sackville, Cumberland and Amhurst. Done by Charles Morris, Chief Surveyor, 1761. MS. 3 miles to 1 inch. Public Records Office, Kew, UK. Accession number: CO700/NOVASCOTIA36

Morse, J., Arrowsmith, A., and Lewis, S. 1814. The American Universal Geography: or, a view of the present state of all the kingdoms, states and colonies in the known world. Lincoln \& Edmands Publishers, Charlestown, 898 p.

Murdoch, B. 1865. A history of Nova-Scotia, or Acadie. J. Barnes, Halifax, 628 p.

Plank, G. 1996. The two majors cope: the boundaries of nationality in mid-18th Century Nova Scotia. Acadiensis 25, pp. 18-40.

Purdy, J. 1814. A map of Cabotia; comprehending the provinces of Upper and Lower Canada, New-Brunswick, and Nova-Scotia, with Breton Island, Newfoundland, \&c. and including also the adjacent parts of the United States. Holmes Laurie, No. 53, Fleet Street, London.
Roberts, O.A. 1895. History of the Military Company of the Massachusetts, now called, the Ancient and Honorable Artillery Company of Massachusetts: 1637-1888. A. Mudge \& Son, Boston.

Robinson, A.H. 1976. Nathaniel Blackmore's plaine chart of Nova Scotia: isobaths in the open sea? Imago Mundi 28, pp. 137-141. doi:10.1080/03085697608592436

Rompkey, R. 1982. Expeditions of honour: the journal of John Salusbury in Halifax, Nova Scotia, 1749-53. University of Delaware Press, 326 p.

Rygel, M.C., and Shipley, B.C. 2005. "Such a section as never was put together before": Logan, Dawson, Lyell, and midnineteenth-century measurements of the Joggins Section. Atlantic Geology 41, pp. 87-102.

Shortt, A., Johnston, V.K., and Lanctôt, G. 1933. Documents relating to currency, exchange and finance in Nova Scotia with prefatory documents, 1675-1758. Public Archives of Canada, Board of Historical Publications, Kings Printer, $495 \mathrm{p}$

Shurtleff, N.B. 1853. Records of the Governor and Company of Massachusetts Bay in New England, 1628-86, Volume 1. Publisher unknown, Boston, $1088 \mathrm{p}$.

Smith, P.H. 1884. Acadia: a lost chapter in American History. Smith Pawlings Publisher, New York, 381 pp.

Smith, T. 1836. A lecture on the geology and mineralogy of Nova Scotia. Magazine of Natural History 21,368-375.

Snowdon, J.D. 1972. The Cumberland Basin grindstone industry. Unpublished BA Thesis, Mount Allison University, Sackville, New Brunswick, 122 p.

Surette, P. 2005. Atlas of the Acadian settlement of the Beaubassin, 1660 to 1755: the Great Marsh, Tintamarre and Le Lac. Tantramar Heritage Trust, Sackville, New Brunswick, $103 \mathrm{p}$.

Thomas, C.E. 1974. Cope, Henry. In dictionary of Canadian biography, volume III, 1741-1770. Edited by W.B. George, J. Hamelin, J., and F.G. Halpenny, University of Toronto Press, pp. 135-136.

Tooker, W.W. 1911. The Indian place-names on Long Island and islands adjacent with their probable significations. G.P. Putnams \& Sons, New York, 314 p.

Trueman, H. 1902. The Chignecto Isthmus and its first settlers. William Briggs, Toronto, $268 \mathrm{p}$.

Wagner, R.L. 1974. Hale, Robert. In dictionary of Canadian biography, volume III, 1741-1770. Edited by W.B. George, J. Hamelin, J., and F.G. Halpenny, University of Toronto Press, pp. 274-275.

Wells, J. 1714. A draft of ye Bay of Fundy, Jan. 8th, 1714. Public Records Office, Kew, UK. Accession number: CO700/ NOVASCOTIA3.

Editorial responsibility: Robert A. Fensome 